\title{
Viral diseases of marine invertebrates
}

\author{
P. T. Johnson \\ National Marine Fisheries Service, Northeast Fisheries Center; \\ Oxford, Maryland 21654, United States of America
}

\begin{abstract}
Approximately 40 viruses are known from marine sponges; turbellarian and monogenetic flatworms; cephalopod, bivalve, and gastropod mollusks; nereid polychaetes; and isopod and decapod crustaceans. Most of the viruses can be tentatively assigned to the Herpesviridae, Baculoviridae, Iridoviridae, Adenoviridae, Papovaviridae, Reoviridae, "Birnaviridae", Bunyaviridae, Rhabdoviridae, and Picornaviridae. Viruslike particles found in oysters might be representatives of the Togaviridae and Retroviridae. Enveloped single-stranded RNA viruses from crustaceans have developmental and morphological characteristics intermediate between families, and some show evidence of relationships to the Paramyxoviridae as well as the Bunyaviridae or Rhabdoviridae. Certain small viruses of shrimp cannot be assigned, even tentatively, to a particular family. Some viruses cause disease in wild and captive hosts, others are associated with disease states but may not be primary instigators, and many occur in apparently normal animals. The frequency of viral disease in natural populations of marine invertebrates is unknown. Several viruses that cause disease in captive animals, with or without experimental intervention, have also been found in diseased wild hosts, including herpeslike viruses of crabs and oysters, iridovirus of octopus, and reolike and bunyalike viruses of crabs. Iridolike viruses have been implicated in massive mortalities of cultured oysters. Baculoviruses, and IHHN virus, which is of uncertain affinities, cause economically damaging diseases in cultured penaeid shrimp. Double or multiple viral infection is common in crabs. For example, a reolike virus and associated rhabdolike virus act synergistically to cause paralytic and fatal disease in Callinectes sapidus. Information on host range, most susceptible stage, and viral latency is available only for viruses of shrimp. One baculovirus attacks five species of New World penaeid shrimp. IHHN virus infects three species of Penaeus and causes catastrophic mortalities in P. stylirostris, but usually exhibits only inapparent infection in $P$. vannamei. Some shrimp viruses apparently are latent in larvae, causing disease only when shrimp have reached the postlarval or juvenile stages. Others are equally or more pathogenic in larvae. Studies of shrimp viruses and iridovirus-associated disease in cultured oysters point up the need for rapid and accurate diagnostic methods. Until appropriate cell cultures from marine invertebrates are devised, the viral identifications necessary for understanding of epizootiology, rapid containment of epizootics in cultured animals, and decisions regarding introductions of exotic species will be difficult or impossible.
\end{abstract}

\section{INTRODUCTION}

Prior to Vago's (1966) report of a virus from a marine crab, invertebrate viruses were known only from terrestrial insects and mites, and a possible virus had been found in an oligochaete (Dougherty et al., 1963). Discovery that a variety of viruses infect marine invertebrates depended to a large extent on the general availability and use of transmission electron microscopes that occurred in the early 1960's. Most of the viruses reported to date were detected by electron microscopy of tissues or isolated virus. Existence of two 
viruses was first deduced by experimental methods, and in the mid 1970's several strains of another virus were isolated in fish-cell cultures from tissues of various mollusks and a crab. A number of the viruses were found by chance in tissues being studied for other reasons. A minority have been strongly associated with disease states in their hosts; and many of the others remain curiosities whose ability to cause disease is not only unknown but unstudied.

This review discusses the occurrence of viruses in the phyla of marine invertebrates and their affinities with groups that infect vertebrates and terrestrial and freshwater invertebrates. Available information on diseases associated with viruses is presented. Synergism between stress factors and viruses in causation of disease, and implications of viral disease for aquaculture, are discussed.

\section{THE VIRUSES AND THEIR HOSTS}

Family names of viruses used in Table 1 are those approved and defined by the International Committee on Taxonomy of Viruses (ICTV) (Matthews, 1982). "Birnaviridae" is not yet an approved name, but is being used by investigators working with IPNV (Infectious Pancreatic Necrosis Virus) of fish, and related viruses from chickens and Drosophila (Dobos et al., 1979).

Few viruses from marine invertebrates can be assigned with certainty to a particular family because biochemical, biophysical, and immunological data are incomplete or lacking. In most cases, morphological and developmental characteristics of the virions, and their location in the cell, allow tentative association with one or more of the recognized families. The enveloped cytoplasmic viruses that are known to , or presumed to, contain single-stranded RNA are particularly difficult to relate to a described family because they appear to share characteristics with more than one. The small viruses of shrimp are of uncertain affinities and are not listed in Table 1. Except where indicated, assignments of viruses to named groups are provisional.

According to Bonami et al. (1971), a virus (or viruses) has been found in echinoderms. I have been unable to confirm this statement by reference to the literature available to me.

\section{Herpesviridae - mollusks, crustaceans}

Species accepted by the ICTV as members of the Herpesviridae are all from mammals and birds, but this committee notes that herpesviruses also occur in coldblooded vertebrates and invertebrates (Matthews, 1982; Buchanan \& Richards, 1982). Several herpeslike viruses cause disease in marine and freshwater fish (McAllister, 1979), and a herpeslike virus has been found in Thraustochytrium sp., an estuarine saprolegnid fungus (Kazama \& Schornstein, 1972). The following three herpeslike viruses are known from marine invertebrates.

The first one to be described was from oysters, Crassostrea virginica, being held at 28 to $30^{\circ} \mathrm{C}$ in the coolant discharge from a fossil-fueled generating plant in Maine. Many died, although normal oysters are unaffected by temperatures in the $30^{\circ} \mathrm{C}$ range. Tissues of 10 dying oysters examined by light microscopy and EM (electron microscopy) had dilated digestive diverticula and cellular infiltrates, sometimes massive, in vesicular connective tissue around hemolymph sinuses. Cells around these sinuses had intranu- 
Table 1. Viral families with known or presumed members in marine invertebrates. $\mathrm{ds}=$ double stranded; $\mathrm{ss}=$ single stranded

\begin{tabular}{|c|c|c|c|}
\hline \multirow[t]{2}{*}{ Family } & \multicolumn{2}{|r|}{ Hosts } & \multirow{2}{*}{$\begin{array}{l}\text { Representative } \\
\text { members }\end{array}$} \\
\hline & Marine invertebrates & Listed by ICTV* & \\
\hline $\begin{array}{l}\text { Herpesviridae } \\
\text { ds DNA, enveloped, } \\
\text { nucleus and } \\
\text { cytoplasm }\end{array}$ & Crabs, oysters & Vertebrates & $\begin{array}{l}\text { Human herpesvirus, } \\
\text { cytomegalovirus }\end{array}$ \\
\hline $\begin{array}{l}\text { Baculoviridae } \\
\text { ds DNA, enveloped, } \\
\text { nucleus, sometimes } \\
\text { cytoplasm }\end{array}$ & Crabs, shrimp** & $\begin{array}{l}\text { Insects, arachnids, } \\
\text { insect - parasitic } \\
\text { fungus? }\end{array}$ & $\begin{array}{l}\text { Nuclear polyhedrosis } \\
\text { viruses - insects }\end{array}$ \\
\hline $\begin{array}{l}\text { Iridoviridae } \\
\text { ds DNA, } \\
\text { nonenveloped, } \\
\text { cytoplasm }\end{array}$ & $\begin{array}{l}\text { Octopus }{ }^{*} \text {, oysters, } \\
\text { polychaete }\end{array}$ & $\begin{array}{l}\text { Insects, fish, frogs, } \\
\text { mammals, } \\
\text { terrestrial isopods, } \\
\text { daphnid } \\
\text { branchiopod }\end{array}$ & $\begin{array}{l}\text { Lymphocystis virus - } \\
\text { fish, iridescent } \\
\text { viruses - insects }\end{array}$ \\
\hline $\begin{array}{l}\text { Adenoviridae } \\
\text { ds, DNA, } \\
\text { nonenveloped, } \\
\text { nucleus }\end{array}$ & Turbellarians, sponge & Birds, mammals & Viral pneumonia virus \\
\hline $\begin{array}{l}\text { Papovaviridae } \\
\text { ds DNA, } \\
\text { nonenveloped, } \\
\text { nucleus }\end{array}$ & Oyster & Mammals & Wart virus \\
\hline $\begin{array}{l}\text { Reoviridae } \\
\text { ds RNA (10-12 } \\
\text { segments), } \\
\text { nonenveloped, } \\
\text { cytoplasm }\end{array}$ & $\begin{array}{l}\text { Trematode, squid, } \\
\text { oysters, parasitic } \\
\text { isopod, crabs }\end{array}$ & $\begin{array}{l}\text { Plants, arthropods, } \\
\text { birds, mammals }\end{array}$ & $\begin{array}{l}\text { Cytoplasmic } \\
\text { polyhedrosis viruses } \\
\text { - insects, tick fever } \\
\text { virus }\end{array}$ \\
\hline $\begin{array}{l}\text { "Birnaviridae" } \\
\text { ds RNA (2 segments), } \\
\text { nonenveloped, } \\
\text { cytoplasm }\end{array}$ & $\begin{array}{l}\text { Bivalves**, } \\
\text { gastropods**, crab }\end{array}$ & Fish, birds, insect & IPN virus - fish \\
\hline $\begin{array}{l}\text { Bunyaviridae } \\
\text { ss RNA, enveloped, } \\
\text { cytoplasm }\end{array}$ & Crabs & $\begin{array}{l}\text { Arthropods, } \\
\text { vertebrates }\end{array}$ & $\begin{array}{l}\text { Arthropod-borne } \\
\text { viruses }\end{array}$ \\
\hline $\begin{array}{l}\text { Rhabdoviridae } \\
\text { ss RNA, enveloped, } \\
\text { cytoplasm }\end{array}$ & Crabs & $\begin{array}{l}\text { Plants, insects, birds, } \\
\text { mammals }\end{array}$ & Rabies virus \\
\hline $\begin{array}{l}\text { Picornaviridae } \\
\text { ss RNA, } \\
\text { nonenveloped, } \\
\text { cytoplasm } \\
\text { * Matthews (1982) } \\
\text { One or more of the } \\
\text { family by the ICTV }\end{array}$ & viruses reported are acce & epted as members or $p$ & bable members of the \\
\hline
\end{tabular}


clear inclusions that contained nonenveloped hexagonal virions, 70 to $90 \mathrm{~nm}$, with either an eccentric electron-dense nucleoid or an empty centre (Fig. 1) (Farley et al., 1972). Enveloped particles, about $250 \mathrm{~nm}$, as well as nonenveloped ones, were associated with probable virogenic stromata in the cytoplasm (Farley, 1978). When searched for, this virus was also found in a small percentage of Maine oysters living in the normal environment.

A herpeslike virus found in mesodermal cells of the male gonad of crabs, Rhithropanopeus harrisii from North Carolina, is nonenveloped in the nucleus but has an envelope in the cytoplasm (Payen \& Bonami, 1979). It is paraspherical and slightly angulate; capsids have variably dense interiors and are 75 to $80 \mathrm{~nm}$. Enveloped virions are 100 to $110 \mathrm{~nm}$. Envelopment apparently occurs during passage from the nucleus to the cytoplasm, as typical of vertebrate herpesviruses. General tissue distribution of this virus is unknown. Pathogenic effects appeared to be limited to degeneration of some infected cells.

The third herpeslike virus (HLV = HerpesLike Virus) infects hemocytes of the blue crab, Callinectes sapidus (Johnson, 1976a). The central cylindrical nucleoid of HLV is surrounded by a toroid and the envelope of a fully developed virion consists of two membranes. The enveloped virion is hexagonal with a diameter of 185 to $214 \mathrm{~nm}$ (Fig. 2) (Johnson, 1983). Entire development, including envelopment, takes place in the greatly hypertrophied nucleus, with viral release through lysis of the nucleus. HLV causes disease and mortality in both captive and wild crabs from the Chincoteague Bay system of Delaware, Maryland, and Virginia.

\section{Baculoviridae - crustaceans}

Baculoviruses are the quintessential nuclear viruses of arthropods. Best known from insects, they also occur in arachnids and marine crustaceans, and a baculolike virus was found in an insect-parasitic fungus (Federici \& Humber, 1977). All described marine members are from penaeid shrimp and brachyuran crabs.

The majority of insect baculoviruses are occluded; that is, virions become embedded in a proteinaceous occlusion body. Nuclear polyhedrosis viruses have many virions contained within an occlusion body that is often polyhedral (Subgroup A). Granulosis viruses are embedded singly, or rarely in pairs, in small occlusion bodies (Subgroup B). Non-occluded baculoviruses lack occlusion bodies and virions lie directly in the nucleoplasm (Subgroups $C$ and D). Subgroups C and D cannot always be distinguished morphologically.

Nuclear polyhedrosis viruses occur in shrimp, and non-occluded baculoviruses infect both shrimp and crabs (Table 2). Granulosis viruses have not been reported from crustaceans. Only Baculovirus penaei has been sufficiently characterized to allow acceptance by the ICTV as a member of the family (Couch, 1981), but the other enveloped rod-shaped nuclear viruses of crustaceans are clearly related to, and most probably are, members of the Baculoviridae. Virions of certain insect-infecting species of Subgroups A and D have two or more nucleocapsids per envelope, but virions of known crustacean-infecting baculoviruses are enveloped singly. Nuclei infected with any of the crustacean baculoviruses are hypertrophied, usually evenly and rather weakly Feulgen positive, and often have a rim of strongly staining chromatin. 


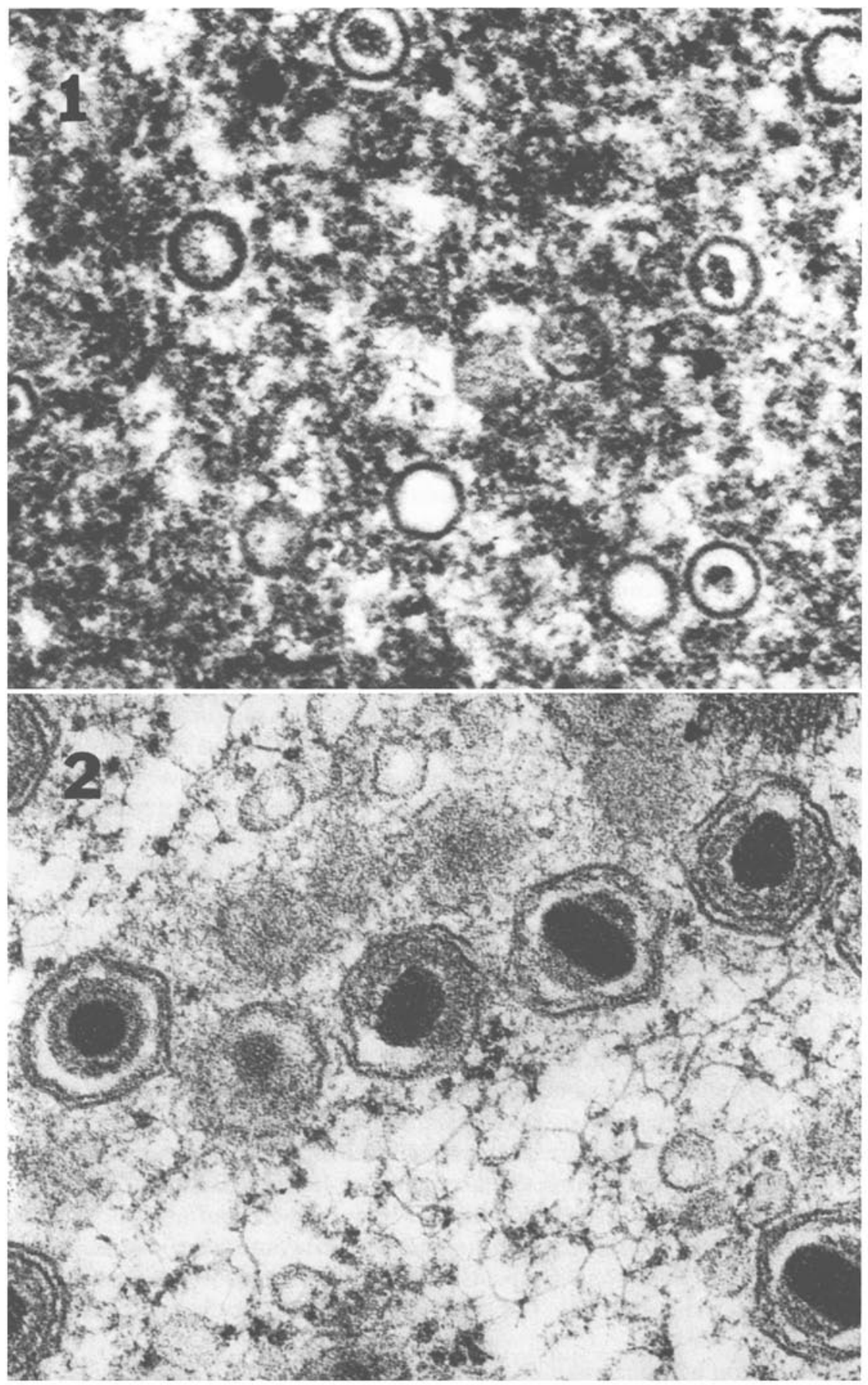

Figs 1 and 2. Electron micrographs of herpeslike viruses, both in the nucleus $(81000 \mathrm{X})$.

Fig. 1. Nonenveloped virus of Crassostrea virginica. Electron micrograph courtesy of C. A. Farley. 
Table 2. Baculoviruses of crustaceans

\begin{tabular}{|c|c|c|c|c|}
\hline Name & $\begin{array}{l}\text { Probable } \\
\text { subgroup }\end{array}$ & Hosts & Tissue attacked & Size \\
\hline $\mathrm{BP}$ & $\mathrm{A}$ & Penaeus spp. (New World) & Hepatopancreas & $75 \times 270 \mathrm{~nm}$ \\
\hline MBV & A & $\begin{array}{l}\text { Penaeus monodon, } \\
\text { Penaeus merguiensis }\end{array}$ & Hepatopancreas & $75 \times 324 \mathrm{~nm}$ \\
\hline BMNV & $\mathrm{C}$ & Penaeus japonicus & Hepatopancreas & $72 \times 310 \mathrm{~nm}$ \\
\hline Baculo-A & $\mathrm{C}$ & Callinectes sapidus & Hepatopancreas & $70 \times 285 \mathrm{~nm}$ \\
\hline Unnamed & $C ?$ & Carcinus mediterraneus & Hepatopancreas & $65-70 \times 300-320 \mathrm{~nm}$ \\
\hline Baculo-B & $\mathrm{C}$ & Callinectes sapidus & $\begin{array}{l}\text { Hemocytes, } \\
\text { hemopoietic tissue }\end{array}$ & $100 \times 335 \mathrm{~nm}$ \\
\hline Unnamed & $\mathrm{C}$ & Carcinus maenas & $\begin{array}{l}\text { Hemocytes, } \\
\text { connective tissue }\end{array}$ & $75-80 \times 230-280 \mathrm{~nm}$ \\
\hline
\end{tabular}

Nuclear polyhedrosis viruses infect seven species of shrimp. BP (Baculovirus penaei) occurs in Penaeus duorarum, $P$. aztecus, and $P$. setiferus from the northern Gulf of Mexico, and probably the same virus occurs in $P$. vannamei and $P$. stylirostris in culture facilities on the Pacific coast of Central America and Ecuador (Couch, 1974a, b, 1978, 1981; Lightner et al., 1983b; Lightner, pers, communication). MBV (Monodon BaculoVirus) infects an Indo-Pacific shrimp, Penaeus monodon, and infection has been noted in Penaeus merguiensis (Lightner \& Redman, 1981; Lightner et al, 1983a, b). Both these viruses attack epithelial cells of the hepatopancreas and occasionally are found in midgut epithelia also. MBV occlusion bodies are multiple and more or less spherical, those of $\mathrm{BP}$ are tetrahedral. $\mathrm{MBV}$ is known only from cultured shrimp, and $\mathrm{BP}$, also discovered in captive shrimp, was later found in wild populations in the Gulf of Mexico (Lightner et al., 1983b; Couch, 1974a, b).

Three non-occluded baculoviruses are found in hepatopancreatic cells of shrimp and crabs. BMNV (Baculoviral Mid-gut gland Necrosis Virus) is known from cultured Japanese shrimp, Penaeus japonicus. This virus causes extensive mortalities in larvae and postlarvae (Sano et al., 1981). Juveniles and adults of the blue crab, Callinectes sapidus, from the Atlantic coast of North America are consistently infected with a nonoccluded hepatopancreatic virus, Baculo-A (Baculovirus A), that apparently does not harm its host (Johnson, 1976b, 1983). Prevalence usually varies from 4 to $20 \%$. Infection is focal, seldom extensive, and is confined to differentiated cells in the epithelium that are continually being replaced by fresh cells. Stem cells are not affected. Development of Baculo-A is associated with intranuclear tubulelike structures. The second hepatopancreatic virus of crabs, from French Carcinus mediterraneus, will cause fatal disease in its host (Pappalardo \& Bonami, 1979). Crabs can be infected experimentally by feeding of infected tissues and by injection of concentrated virus, and virus can be recovered 10 days following infection. Nucleocapsids of the Carcinus virus are strongly curved or flexed when within the envelope. If the envelope is ruptured, the nucleocapsid becomes straight.

The remaining non-occluded baculoviruses from crabs attack hemocytes, hemopoietíc cells, and connective-tissue cells. Baculo-B (Baculovirus B) infects hemocytes and hemopoietic tissue of blue crabs from Chesapeake Bay, Maryland (Johnson, 1983). A 
similar virus infects hemocytes and connective tissue of Carcinus maenas from the French Mediterranean coast (Bazin et al., 1974). Development of both viruses is associated with vesicles in the nucleus. Unlike the case with other crustacean baculoviruses, hypertrophied nuclei infected with Baculo-B are strongly, not weakly, Feulgen positive. The effect of the two viruses on their hosts is unknown. The Carcinus virus was found during a study of limb regeneration, and Baculo-B occurred either in blue crabs of normal appearance or in ones infected with other viruses.

\section{Iridoviridae - mollusks, annelids}

Iridoviruses infect a broad range of animals from insects, freshwater daphnids, and terrestrial isopods to mammals, and include lymphocystis virus of fish. Some species have a broad host range, and iridoviruses often have been implicated in disease, usually chronic, of their invertebrate hosts. Ohba \& Aizawa (1979) demonstrated that an iridovirus from a lepidopteran, CIV (Chilo Iridescent Virus), will infect not only many insects of six orders but also species of the terrestrial isopods Armadillidium and Porcellio and the centipede Thereuonema. CIV did not infect a grapsid crab, a millipede, a diplopod, and a spider. Mice are killed by CIV (Ohba \& Aizawa, 1982) and that virus, as well as one isolated from Armadillidium, cause fatal disease in the frog Rana limnocharis (Ohba \& Aizawa, 1981). The iridovirus of Armadillidium will infect both lepidopterous (Ohba et al., 1982) and coleopterous insects (Cole \& Morris, 1980).

Marine viruses allied to the Iridoviridae occur in cephalopod and bivalve mollusks, and in polychaetes. Rungger et al. (1971) described a fatal disease of Mediterranean Octopus vulgaris characterized by nodular tumors in muscle. The virus associated with the lesions is hexagonal in section and measures about 100 to $140 \mathrm{~nm}$. Staining characteristics, morphology, and development indicate that this virus is an iridovirus. First seen in captive octopus, diseased specimens were later collected from nature.

The Portuguese oyster, Crassostrea angulata, and imported Japanese oysters, Crassostrea gigas, on the French coast are infected by similar or identical iridolike viruses, 350 and $400 \mathrm{~nm}$ in diameter, respectively (Comps \& Duthoit, 1976; Comps et al., 1976; Comps \& Bonami, 1977). Elston (1979) reported a smaller iridolike virus, $228 \mathrm{~nm}$, in velar cells of larval $C$. gigas from a Washington State oyster hatchery. In all cases, viral infection was found in animals from populations undergoing mortalities.

The polychaete virus, 165 to $185 \mathrm{~nm}$, was found in male gonadal cells of Nereis diversicolor collected near Boulogne, France (Devauchelle \& Durchon, 1973; Devauchelle, 1977). Only maturing gametocytes are attacked, spermatids are not formed, and the host is rendered sterile. Injection of virus concentrated from infected tissue results in $100 \%$ infection of normal male worms. Pellets of this virus exhibit an iridescence typical of insect iridoviruses. Virions contain DNA and have morphological and developmental characteristics that place the virus in the Iridoviridae. It has been named NIV (Nereis Iridescent Virus).

\section{Adenoviridae - sponge, turbellarians}

These nuclear viruses, measuring 70 to $90 \mathrm{~nm}$, are known from mammals and birds. Adenolike viruses have been found in cultured freshwater cnidarians, Hydra vulgaris 
(Bonnefoy et al., 1972), and spiders, Pisaura mirabilis (Bergoin \& Morel, 1978; Bergoin et al., 1982). Three viruses of lower marine invertebrates are like adenoviruses of vertebrates morphologically and by their nuclear location. The three were discovered by chance in animals being examined by EM for other purposes, and except for local or cytopathic effects, did not cause overt disease in their hosts.

An adenolike virus was found in only one of more than 100 sponges, Verongia cavernicola, collected near Marseilles, France (Vacelet \& Gallissian, 1978). The isometric virions, 55 to $60 \mathrm{~nm}$, are smaller than vertebrate adenoviruses but similar in appearance. They occurred in a part of the sponge that lacked choanocytes and exhibited other abnormalities including presence of giant cells whose nuclei contained the virus. Smaller isometric particles in cytoplasmic inclusions were found in the same sponge, and in one case, in the same cell containing the nuclear virus. See further discussion under the Picornaviridae.

Two adenolike viruses have been reported from European turbellarian flatworms, and both were in nuclei of probable gland cells. Oschman (1969) described intranuclear virions, approximately $100 \mathrm{~nm}$, in an individual of Convoluta roscoffensis from a laboratory colony, and Reuter (1975) discovered a similar, but smaller, virus, 60 to $70 \mathrm{~nm}$, in an unspecified number of Gyratrix hermaphroditus collected from the wild in Finland. In heavily infected Gyratrix cells, virus was present in both nucleus and cytoplasm. This virus produced abnormalities in infected cells that could be observed with the light microscope.

\section{Papovaviridae - oysters, clam}

Accepted members of the Papovaviridae are known only from mammals, and may be associated with neoplasia in their hosts. The papovalike virus of oysters causes extreme enlargement of nuclei of cells of the germinal tissues of Crassostrea virginica (Fig. 3) (Farley, 1976). The angulate virions measure about $53 \mathrm{~nm}$, within the size range of the papovaviruses. Dense concentrations of virus occur in infected nuclei, and the strong Feulgen reaction in such nuclei gives presumptive evidence that the virus contains DNA. Only small numbers of infected nuclei are present, and except for lysis of infected cells, apparently this virus does not harm its host (C. A. Farley, pers. communication). Based on light microscopy, Farley (1978) reported that similar viruses may occur in gonadal cells of Crassostrea gigas, C. commercialis, Ostrea edulis, and O. Iurida.

A second papovalike virus was found in 10 of 50 clams, Mya arenaria, from Massachusetts (Farley, 1976, 1978). Hemocytes, connective tissues, and gill epithelium were infected. Virus-containing nuclei were hypertrophied and contained Feulgenpositive inclusions. These inclusions contained isometric, nonenveloped virions, 40 to $45 \mathrm{~nm}$. Harshbarger et al. (1977) reported a similar virus from hemocytes of $M$. arenaria from Maine. That virus measured $55 \mathrm{~nm}$. Despite the reported size differences, it seems likely that the viruses are the same species.

Reoviridae - monogenetic trematode, squid, oyster, parasitic isopod, crabs

Viruses in this family infect a broad range of hosts, including plants, insects and ticks, mammals, and birds. Some are transmitted to vertebrates by insects and ticks, and to plants by insects. The cytoplasmic polyhedrosis viruses of insects are included in the 


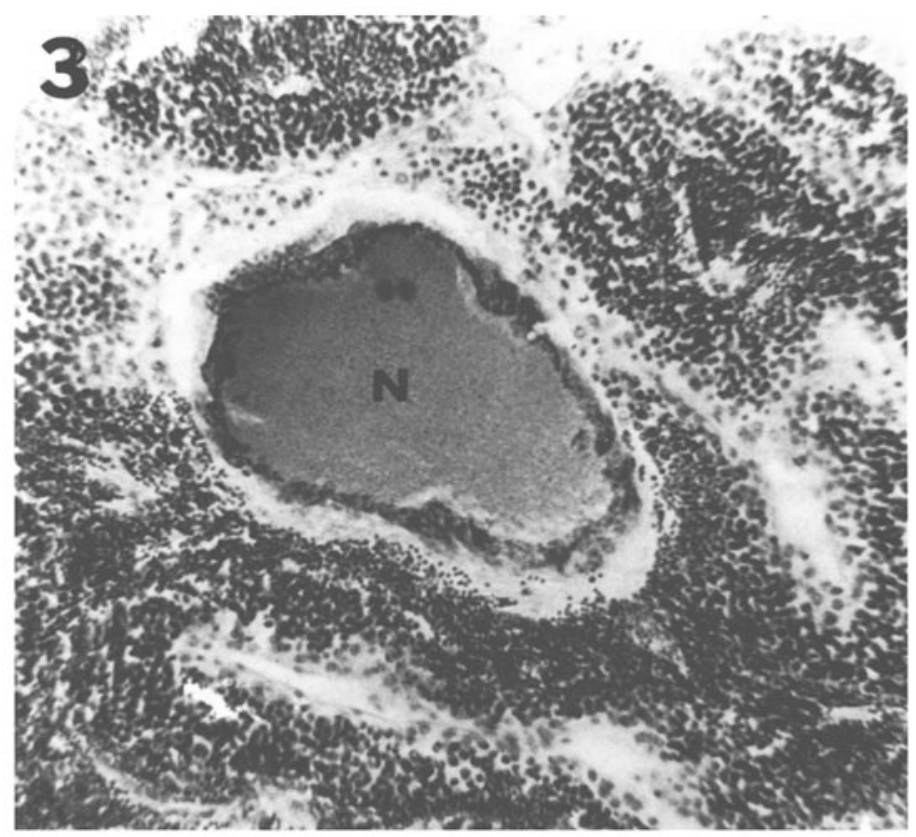

Fig. 3. Gametocyte of Crassostrea virginica infected with a papovalike virus. The greatly hypertrophied nucleus is surrounded by a thin rim of cytoplasm. The numerous small cells are sperm. $\mathrm{N}=$ infected nucleus, Feulgen stained, $300 \mathrm{X}$. (Photograph courtesy of C. A. Farley)

Reoviridae, and a cytoplasmic polyhedrosis virus is found in the freshwater daphnid crustacean, Simocephalus exspinosus (Federici \& Hazard, 1975), Several reolike viruses occur in marine trematodes, mollusks, and crustaceans.

The reolike viruses of a monogenetic trematode, a squid, and an oyster apparently do not damage their hosts. The trematode virus was found in an unstated number of Diplectanum aequans taken from the gills of a sea bass, Dicentrarchus labrax (MokhtarMaamouri et al., 1976). The polygonal virions infected the cytoplasm of parenchymal cells, measured 66 to $70 \mathrm{~nm}$, and often occurred in large paracrystalline arrays. The virus of squid, Sepia officinalis, was found in stomach cells of a single specimen collected off the French coast (Devauchelle \& Vago, 1971). Size $(75 \mathrm{~nm})$, morphology, and development are like those of the Reoviridae. Both the above viruses were found during EM examinations being performed for other reasons. The oyster virus was isolated from larvae of Crassostrea virginica in fish-cell cultures (blue gill fibroblast, BF-2) (Meyers, 1979). Several other fish-cell lines were also susceptible. Isolations were made from three pools of larval oysters from two hatcheries on Long Island Sound, New York, during screening for indigenous viruses. This virus, $79 \mathrm{~nm}$, is icosahedral and capsomere structure is apparently like that of the Reoviridae (Meyers \& Hirai, 1980). It is not similar to infectious pancreatic necrosis virus (IPNV) of fish, based on its different size and morphology, and its failure to be neutralized by a polyvalent IPNV antiserum. It was presumed not to be a contaminating vertebrate reovirus by immunologic differences and because it did not cause CPE (cytopathic effect) in mammalian and avian cell cultures known to support various reovirus serotypes. 
A reolike virus, $58 \mathrm{~nm}$, was found in tissues of parasitic isopods, Portunion conformis, infected with a picornalike virus. The two viruses sometimes occurred in the same cell (Kuris et al., 1979). The reolike virus was much less abundant than the picornalike virus, and its ability to cause disease is unknown. It did not occur in tissues of the host crabs.

The three reolike viruses reported from crabs are associated with fatal disease of their hosts. The P virus (Paralysis Virus) of Macropipus depurator was the first virus described from a marine invertebrate (Vago, 1966). It was found by EM examination of tissue suspensions concentrated by centrifugation, and occurred in wild, diseased crabs with progressive paralysis that were collected from the French Mediterranean coast. The P virus has been partially characterized (Bonami, 1973; Bonami et al., 1976; Bergoin et al., 1982). It is icosahedral and $58-65 \mathrm{~nm}$. The genome consists of 10 segments of doublestranded RNA, like the Reoviridae and unlike the birnaviruses, which are similar in size and appearance but have bisegmented RNA. Whether the $P$ virus causes necrosis in nervous tissue leading to the paralysis typical of the disease has not been reported. $A$ similar virus, RLV (ReoLike Virus), is involved in fatal disease in laboratory-maintained blue crabs, Callinectes sapidus, from Chesapeake Bay, Maryland (Johnson \& Bodammer, 1975; Johnson, 1977, 1983). RLV is also associated with paralysis of the host. An enveloped virus (S virus) is usually found with the P virus in $M$. depurator (Bonami, 1973), and a rhabdolike virus (RhVA) was always found with RLV in tissues of diseased, paralyzed blue crabs examined by EM (Johnson, 1983). RLV and RhVA act synergistically to produce the characteristic paralysis. The gill virus of Carcinus mediterraneus also causes fatal disease and is similar morphologically to P virus and RLV. Injection of purified virus or contact with diseased tissues causes death in 8 days. This virus forms ring-shaped aggregates in gill epithelial cells and may completely destroy the gill epithelium (Bonami, 1976; Bergoin et al., 1982).

\section{"Birnaviridae" - mollusks, crab}

Members of this group infect fish, fowl, and an insect, Drosophila. The best known

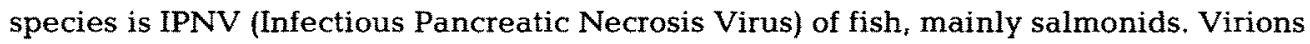
of birnaviruses are about $60 \mathrm{~nm}$, icosahedral, and have 92 morphological subunits. Birnaviruses differ from the Reoviridae biophysically and immunologically. They have only two segments of double-stranded RNA in the genome, rather than 10 to 12 as in Reoviridae, and capsid morphology is different. They are smaller than many reoviruses, but similar in appearance by EM examination of thin-sectioned tissues. Morphologic criteria, as seen by examination of thin sections, do not serve reliably to separate viruses of these two groups.

The birnaviruses associated with marine mollusks and a crab were all isolated in fish-cell cultures at the Weymouth, England, Fish Diseases Laboratory (Hill, 1976a, b). Isolations were from the bivalves Tellina tenuis, Crassostrea gigas, C. virginica, Ostrea edulis, and Mercenaria mercenaria; the gastropods Patella vulgata and Littorina littorea; and the crab Carcinus maenas. One isolation was made from tissues of Canadian $C$. virginica; and 12 were from animals collected along the coasts of England and Scotland. Apparently all the viral strains tested belong to one of the known serotypes of IPNV, although reports differ concerning one isolate from Tellina and one from $O$. edulis (Hill, 
1976a, b; Underwood et al., 1977; Dobos et al., 1979; MacDonald \& Gower, 1981). None of the isolated strains tested appear to be markedly pathogenic, but there is some evidence of a mild pathogenic effect on the digestive gland of normal $O$. edulis exposed to cultured virus isolated from $O$. edulis and Tellina (Hill \& Alderman, 1977), and there may have been increased mortality in groups of $O$. edulis and $C$. gigas exposed to strains from $O$. edulis and $C$. virginica (Hill et al., 1982). Virus was recovered from C. gigas and Tellina for a considerable period after they had been exposed, through water, to an isolate from Tellina (Hill, 1976b), and virus was recovered from $O$. edulis and C. gigas exposed to strains from $O$, edulis and $C$. virginica (Hill et al., 1982).

Confusion exists in the earlier literature on the virus from Tellina (Buchanan, 1973; Hill, 1976a, b; Underwood et al., 1977). Buchanan (1973) reported an icosahedral $70 \mathrm{~nm}$ virus in the digestive gland of abnormal Tellina that had chalky, brittle shells and discolored digestive glands. Hill isolated a smaller virus ( 55 to $60 \mathrm{~nm}$ ) from the diseased clams, and originally it was believed to be the one seen by Buchanan (Hill, 1976a). However, the virus seen by Buchanan was discovered to be a phage within a rickettsia, and the rickettsia was responsible for disease in the clams (Buchanan, 1978). The birnavirus from Tellina was not seen in tissues of the group of diseased clams used for its isolation, but cytoplasmic paracrystalline arrays of a virus similar to that from Tellina were seen in thin sections of the digestive gland of an oyster, C. gigas, that had been exposed through water to the Tellina virus (Hill, 1976a).

\section{Bunyaviridae - crabs}

These spherical to oval viruses, 90 to $100 \mathrm{~nm}$ in diameter, are arthropod-borne viruses of warm- and cold-blooded vertebrates. Their arthropod hosts include insects and ticks. Bunyaviruses mature by budding into vesicles of smooth endoplasmic reticulum associated with the Golgi complex. Three viruses of crabs appear to be more closely related to the Bunyaviridae than other families of viruses. The three are all found in cytoplasmic vesicles, and there are indications of budding into the vesicles in two of them.

Bang $(1971,1974)$ deduced the presence of a virus in crabs, Carcinus maenas, that developed a defect in the clotting mechanism after being injected with hemolymph from a wild crab suffering the same defect. The causative agent was filterable and EM examination of hemocytes taken from an experimentally infected crab showed spherical particles of virus in the endoplasmic reticulum. Hoover (1977) reported that this virus, CHV (Crab Hemocytopenic Virus), also called "Roscoff Virus" (Bang, 1983), measures 55 to $80 \mathrm{~nm}$, attacks hemocytes, particularly granulocytes, and apparently buds into the cytoplasmic vesicles where it is found. Except for its somewhat smaller size, it appears like a bunyavirus. CHV was isolated from one of more than 600 crabs being bled for another purpose, at Roscoff, France. It has not been found again.

$\mathrm{Y}$-organs of several Carcinus mediterraneus being examined by EM during investigations of Sacculina infection, contained an oval virus, $60 \times 180 \mathrm{~nm}$, that packed cytoplasmic vesicles (Zerbib et al., 1975; Bonami, 1976). It occurred in normal and parasitized crabs. There is no further information on this virus.

The best characterized bunyalike virus is the $\mathrm{S}$ virus (Sète virus) of Mediterranean Macropipus depurator. It has also been found in Carcinus mediterraneus, and causes 
disease in the natural environment (Bonami \& Vago, 1971; Bonami et al., 1971, 1975; Bergoin et al., 1982). The virus also shows characteristics of the Paramyxoviridae. The genome of the $\mathrm{S}$ virus contains single-stranded RNA, and some of its physical and other chemical attributes have been determined (Bonami et al., 1975; Bergoin et al., 1982). The virus is pleomorphic, being spherical, oval, or elongate in material obtained by densitygradient centrifugation of hemolymph and other tissues, but in thin sections of heart and connective tissues only ovoid and spherical forms, 100-120 $\times 200 \mathrm{~nm}$, were found. Virions develop in cytoplasmic vesicles (Bonami et al., 1971, 1975). Usually associated with the $\mathrm{P}$ virus of $M$. depurator, it causes fatal disease when separated and injected into normal crabs (Bonami \& Vago, 1971).

\section{Rhabdoviridae - crabs}

Members of this family are found in plants, invertebrates (arthropods), and vertebrates. Most known animal rhabdoviruses are bullet-shaped and relatively large $(70 \times 170 \mathrm{~nm})$. Plant rhabdoviruses, accepted as such by the ICTV, are usually bacilliform, often of smaller diameter, and may be much longer (45-95 $\times 135-380 \mathrm{~nm})$. Some vertebrate and plant rhabdoviruses multiply in insects, transmission by arthropod vectors occurs with both, and congenital transmission is found in a Drosophila virus (Sigma virus). Formation of mature virions is either by budding into cytoplasmic vesicles or through the plasma membrane into extracellular space, depending on the virus and the host-cell type.

Four viruses from crabs may be related to the Rhabdoviridae. Nucleocapsid formation in two of the larger three is like that of the Paramyxoviridae. Areas of nucleocapsid formation were not seen with the third. All the crab viruses are either bacilliform or oval, not bullet-shaped, and diameter of the small virus is less than that of the smaller plant rhabdoviruses accepted by the ICTV. Similar small viruses are found in plants (Allen, 1972) and insects (Morrissey \& Edwards, 1977; Adams et al., 1980).

By chance, extracellular particles of an oval to bacilliform virus were found associated with the basal lamina of blue-crab, Callinectes sapidus, mandibular glands (erroneously referred to in the paper as the Y organ [ecdysial gland]) by Yudin \& Clark (1978). Its discoverers called this virus EGV-1 (Ecdysial Gland Virus-1). Johnson (1983) redesignated it RhVB (Rhabdolike Virus B). The virion measures $50-70 \times 100-170 \mathrm{~nm}$, and has surface projections on the envelope. The two infected crabs were apparently normal, and RhVB occurred with another rhabdolike virus in one of them.

A second virus, EHV (Enveloped Helical Virus), from the blue crab is similar in shape to RhVB, but larger $(105 \times 194-300 \mathrm{~nm})$. This virus was compared to the Paramyxoviridae by Johnson \& Farley (1980). It buds from the plasma membrane, has surface projections on the envelope, and mature virions are extracellular and often associated with the basal lamina. Granular virogenic stromata in the cytoplasm contain sinuous helical nucleocapsids. Virus was seen budding from hemocytes and hemopoietic-tissue cells, and was associated with the basal lamina of certain connective-tissue cells. EHV always occurred with other viruses and its effect on the host is unknown (Johnson, 1983).

The Y-organ virus of Carcinus maenas develops like EHV, and mature virions were located within and beneath the basal lamina of infected $\mathrm{Y}$-organs (Chassard-Bouchaud 
\& Hubert, 1975; Chassard-Bouchaud et al., 1976). The virus is ovoid to elongate, 70-90 $\mathrm{nm} \times 150-170 \mathrm{~nm}$. It was found during EM investigations of $\mathrm{Y}$-organs of crabs collected at Roscoff, France. Other tissues were not investigated.

The smallest rhabdolike virus, RhVA (Rhabdolike Virus A), is from the blue crab and occurs in populations from the Atlantic and Gulf coasts of North America. Jahromi (1977), Johnson (1978), and Yudin \& Clark $(1978,1979)$ found RhVA (designated EGV-2 $=$ Ecdysial Gland Virus-2, by the latter authors, who confused the ecdysial gland with the mandibular gland) in crabs stressed by culture conditions, infections with other viruses, or eyestalk ablation, respectively. RhVA is either bacilliform with rounded ends and $20-30 \times 110-170 \mathrm{~nm}$, or flexuous, the same diameter, and up to $600 \mathrm{~nm}$ in length. It buds into the endoplasmic reticulum and, more rarely, buds from the inner nuclear membrane. Johnson $(1978,1983)$ found RhVA in many different tissues. It occurs regularly in glial cells of ganglia and the larger nerves, and is common in hemocytes, connective tissues, and various epithelia excepting those of gut and antennal gland. It does not infect striated muscle, and apparently does not infect the Y-organ (Johnson, 1983), but it is found in the mandibular gland (Yudin \& Clark, 1978, 1979). In all cases investigated with EM by Johnson $(1978,1983)$, RhVA occurred in company with one or more other viruses. Crabs infected with RLV (ReoLike Virus) always had an associated infection with RhVA, and these two viruses were together responsible for the glial necrosis typical of this mixed infection.

\section{Picornaviridae - crabs, parasitic isopod}

These small cytoplasmic viruses infect mammals and insects, and are usually host specific. Four and possibly more picornalike viruses are found in marine crustaceans.

Kuris et al. (1979) discovered a spherical, $25 \mathrm{~nm}$, cytoplasmic virus widely distributed in tissues of three specimens of a parasitic isopod, Portunion conformis, and also in tissues of the host crabs, Hemigrapsus oregonensis, taken from San Francisco Bay, California. Often, paracrystalline arrays of virus, associated with fibrils, filled the cytoplasm of infected cells. Preliminary physicochemical studies indicate a close relationship to the Picornaviridae. A reolike virus occurred with the picornalike virus but in lesser numbers. Although the infected isopods appeared grossly normal, Kuris et al. (1979) note that dead isopods have been found within their hosts, and suggest that parasite mortality should be studied with respect to possible viral disease.

A picornalike virus of the blue crab, Callinectes sapidus, CBV (Chesapeake Bay Virus), is slightly angulate and about $30 \mathrm{~nm}$ in diameter. Like the isopod virus, particles of CBV fill infected cells, sometimes in paracrystalline array. The virions are associated with, and often line up next to, membranes in the cytoplasm. Infected cells often are hypertrophied. Viral inclusions are Feulgen negative, presumptive evidence that the virus contains RNA. CBV occurred in a group of young crabs collected from Chesapeake Bay, Maryland. It caused fatal but often prolonged disease within the group, which was also infected with RLV, RhVA, and EHV (Johnson, 1978, 1983).

Two small isometric viruses, 24 and $31 \mathrm{~nm}$, respectively, (F-N virus), infect cytoplasm of hemocytes and connective-tissue cells of Macropipus depurator (Bonami, 1976; Bergoin et al., 1982). These viruses, when separated by gel diffusion and injected into normal crabs, will separately cause fatal disease. 
A sponge, Verongia cavernicola, infected with an adenolike virus, also had smaller ( 35 to $40 \mathrm{~nm}$ ) particles in inclusions in the cytoplasm (Vacelet \& Gallissian, 1978), and in one case both the adenolike virus and the viruslike cytoplasmic particles were found in the same cell. The cytoplasmic particles were associated with membranes, and sometimes in concentric array. They were larger than picomaviruses, which are 22 to $30 \mathrm{~nm}$, but formation of arrays in association with membranes is typical of that group of viruses.

\section{Viruses of uncertain affinities - shrimp}

Recently a highly lethal disease of cultured shrimp was described by Lightner et al. (1983a, c, d) and Bell \& Lightner (1983). The syndrome was named IHHN (Infectious Hypodermal and Hematopoietic Necrosis) to describe the principal lesions found. IHHN caused catastrophic mortalities in cultured Penaeus stylirostris, of Central and South American origin, that were being reared in Hawaii. IHHNV also infects another Pacific shrimp, Penaeus vannamei, and the Indo-Pacific shrimp Penaeus monodon (Bell \& Lightner, 1983; Lightner et al., 1983c). It can be transmitted by injection of $0.45 \mu \mathrm{m}-$ filtered tissue suspensions, proving its viral nature. Tissues undergoing necrosis contain cells that have hypertrophied nuclei with marginated chromatin and conspicuous eosinophilic inclusions, referred to by Lightner et al. (1983c) as Cowdry Type A inclusions (Fig. 4).

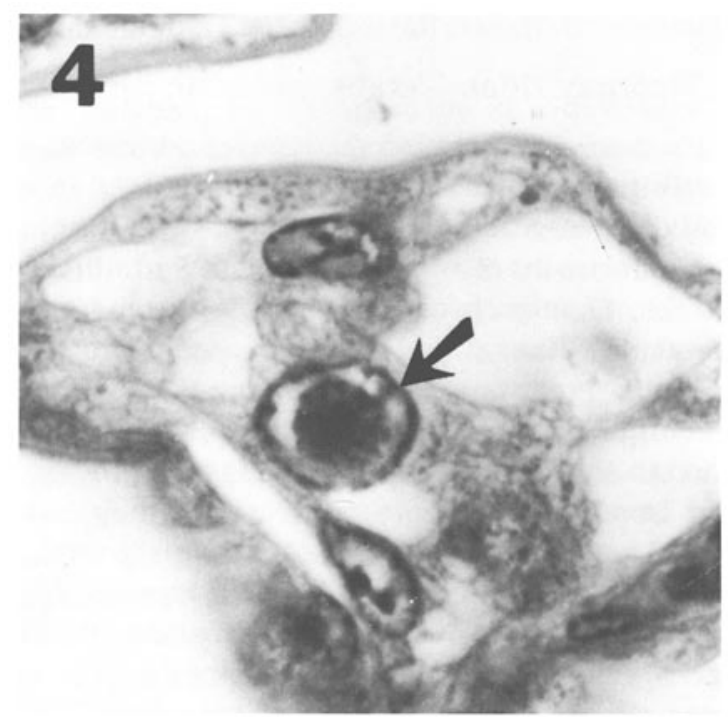

Fig. 4. Gill tissue of Penaeus stylirostris infected with IHHNV. Arrow indicates a hypertrophied nucleus with a Cowdry Type A inclusion, $1650 \mathrm{X}$. (Photograph courtesy of D. V. Lightner)

Three particles, designated types 1,2 and 3, occur in cells of the necrotic areas (Lightner et al, 1983c). Type 1 particles are most common. They are icosahedral, $27 \mathrm{~nm}$, and form small aggregates in the cytoplasm. Type 2 particles are rare, $17 \mathrm{~nm}$, and occur in prominent crystalline arrays within membrane-bounded cytoplasmic inclusions. Type 3 particles are $20 \mathrm{~nm}$ and found in association with apparent virogenic stromata 
within hypertrophied nuclei. These nuclei represent the inclusion-containing nuclei seen with the light microscope. Whether all the particles found represent events in the development of a single virus is not evident. Lightner and coworkers noted similarities with both the cytoplasmic RNA-containing Picornaviridae and the DNA-containing Parvoviridae, nuclear viruses whose development and replication are associated with complex morphological changes in the cytoplasm. Further, some parvoviruses require helper viruses for measurable replication (Matthews, 1982).

Viruslike particles, $23 \mathrm{~nm}$, were found by EM examination in fixed phagocytes of a shrimp, Penaeus aztecus, from the Gulf of Mexico (Foster et al., 1981). Aggregations of particles were seen in three phagocytes and in one case they were partially enclosed by a membrane. Foster et al. raise the possibility that the aggregates could represent phage within partially lysed bacteria, rickettsiae, or chlamydiae. If not phage, the particles are in the size range of picorna- and parvoviruses.

\section{Particles suggestive of virus - bivalve mollusks}

Farley (1978) pictured extracellular, $50 \mathrm{~nm}$, enveloped, viruslike particles that appear to have budded from the plasma membrane of Ostrea edulis hemocytes. Only one case was recognized. This author related the particles to the Togaviridae, a group of cytoplasmic, single-stranded RNA viruses. Hosts of togaviruses are vertebrates, bloodsucking arthropods, and possibly plants. Many arthropod-borne viruses belong to this group.

Budding structures strongly resembling C-type particles of the Retroviridae were seen in the digestive-gland epithelium of an oyster, Crassostrea virginica (Farley, 1978, 1981). The retroviruses are cytoplasmic, bud through the plasma membrane, and contain single-stranded RNA. They infect a broad range of mammals, birds, and reptiles. Most species are transmitted as a part of the germ plasm. Many of these viruses are oncogenic, but some do not cause disease.

Putative C-type particles were also reported by Oprandy et al. (1981) from clams, Mya arenaria from Rhode Island, with hemopoietic neoplasms. The particles were detected by EM examination of negatively-stained material recovered by densitygradient centrifugation of homogenized whole clams. Non-neoplastic clams injected with the same material had a 31 to $46 \%$ prevalence of neoplasia within 2 to 5 months. Control groups did not develop neoplasia. Hemopoietic neoplasms are enzootic in species of clams, oysters, and mussels from many parts of the world. Although the findings of Oprandy et al. (1981) are suggestive of a viral etiology, an attempt to isolate virus from neoplastic mussels, Mytilus edulis from Oregon, was not successful (Mix, 1982). Literature on hemopoietic neoplasms of bivalve mollusks is extensive. The condition was first reported by Farley (1969), and in addition to the citations already given, some of the more recent papers are: Mix et al. (1979); Brown (1980); Balouet et al. (1982); Cooper \& Chang (1982); Cooper et al. (1982a, b); and Reinisch et al. (1983).

\section{DISEASES CAUSED BY THE VIRUSES}

Little is known about the pathogenicity of viruses in wild populations of marine invertebrates, or the place of multiple viral infection in disease causation. Host range has 
been studied in only a few cases. Several of the viruses have been found in sick, wild hosts; others were discovered in diseased captives living in laboratory tanks or being reared in aquaculture facilities (Table 3). There are many indications that stress is an important factor in causation of overt viral disease in captive animals.

Our broadest information on viral disease in marine invertebrates comes from observations on baculoviruses and IHHNV in cultured penaeid shrimp (Couch, 1974a, b, 1981; Couch \& Courtney, 1977; Sano et al., 1981; Bell \& Lightner, 1983; Lightner et al., 1983a, b, c, d; Brock et al., 1983). These papers include studies on the histopathology, progress of infection, mortality rates, transmission, and host ranges of the shrimp viruses, as well as documentation on how stressors may enhance viral prevalence, infection, and disease. They shall serve as models with which to compare the more scattered information available on other disease-causing viruses.

Discussion will be limited to viruses listed in Table 3 . There is insufficient information about diseases caused by five of the viruses listed in Table 3 to warrant discussion

Table 3. Viruses found in diseased marine invertebrates

\begin{tabular}{|c|c|c|c|c|c|}
\hline Virus & Host & $\begin{array}{l}\text { Host status } \\
\text { (wild or } \\
\text { captive) }\end{array}$ & $\begin{array}{l}\text { Strong } \\
\text { association } \\
\text { of virus with } \\
\text { disease }\end{array}$ & $\begin{array}{l}\text { Transmitted } \\
\text { experimen- } \\
\text { tally }\end{array}$ & Reference \\
\hline Herpeslike (HLV) & Crab & W, C & + & + & Johnson (1976a) \\
\hline Herpeslike & Oyster & W, C & + & & Farley et al. (1972) \\
\hline Baculovirus (BP) & Shrimp & $\mathrm{W}, \mathrm{C}$ & + & & Couch (1974) \\
\hline Baculovirus (BMNV) & Shrimp & $\mathrm{C}$ & + & + & Sano et al. (1981) \\
\hline Baculovirus (MBV) & Shrimp & $\mathrm{C}$ & + & & $\begin{array}{l}\text { Lightner \& Redman } \\
\text { (1981) }\end{array}$ \\
\hline $\begin{array}{l}\text { Baculovirus, } \\
\text { hepatopancreas }\end{array}$ & Crab & $? W^{*}, C$ & + & + & $\begin{array}{l}\text { Pappalardo \& Bonami } \\
\text { (1979) }\end{array}$ \\
\hline Iridovirus & Octopus & $\mathrm{W}, \mathrm{C}$ & + & & Rungger et al. (1971) \\
\hline Iridovirus (NIV) & Polychaete & $2 W^{*}, C$ & + & + & $\begin{array}{l}\text { Devauchelle \& } \\
\text { Durchon (1973) }\end{array}$ \\
\hline Iridovirus & Oysters & W & $?$ & & $\begin{array}{l}\text { Comps et al. }(1976) \\
\text { Comps \& Bonami } \\
(1977)\end{array}$ \\
\hline Iridovirus & $\begin{array}{l}\text { Larval } \\
\text { oysters }\end{array}$ & $\mathrm{C}$ & $?$ & & Elston (1979) \\
\hline Reolike ( $\mathrm{P}$ virus) & Crab & $\mathrm{W}, \mathrm{C}$ & + & + & Vago $(1966)$ \\
\hline Reolike (gill virus) & Crab & $? W^{*}, \mathrm{C}$ & + & + & Bonami (1976) \\
\hline $\begin{array}{l}\text { Reolike + Rhabdolike } \\
\text { (RLV + RhVA) }\end{array}$ & Crab & C & + & + & Johnson (1977) \\
\hline Bunyalike (S virus) & Crab & $\mathrm{W}, \mathrm{C}$ & + & + & Bonami \& Vago (1971) \\
\hline Bunyalike (CHV) & Crab & W & + & + & Bang (1971) \\
\hline Picornalike (CBV) & Crab & $\mathrm{C}$ & + & & Johnson (1983) \\
\hline Picornalike (F-N) & Crab & $? W^{*}, C$ & + & + & Bonami (1976) \\
\hline $\begin{array}{l}\text { Affinities unknown } \\
\text { (IHHINV) }\end{array}$ & Shrimp & $\mathrm{C}$ & + & + & Lightner et al. (1983c) \\
\hline
\end{tabular}


beyond that given earlier. These viruses are: hepatopancreatic baculovirus of Carcinus maenas, gill virus of $C$, mediterraneus, F-N virus of Macropipus depurator, herpeslike virus from Crassostrea virginica, and NIV of Nereis diversicolor.

Baculoviruses of shrimp. All these viruses are usually confined to the hepatopancreatic epithelium, but in severe infections or in larvae or young postlarvae, depending on the viral species, the midgut epithelium is also infected. They have not been seen in other tissues. The pathogenic effect is progressive necrosis of the epithelium, with sloughing of infected cells into the lumen of the gut. In severe cases, this leads to dysfunction of the hepatopancreas and death of the host. Detailed information on changes in infected cells at the ultrastructural level is available for the three known shrimp baculoviruses (Couch, 1981; Sano et al., 1981; Lightner et al., 1983b).

The hepatopancreatic epithelium is constantly renewed by stem cells in the apices of the tubules, and recovery from these viruses is finally dependent upon the ability of the host to repopulate the hepatopancreas with noninfected cells. There is no indication that hemocytes respond to the viruses themselves, although hemocytes will encapsulate necrotic hepatopancreatic tubules (Lightner \& Redman, 1981). Lightner et al. (1983b) report one instance of apparent phagocytosis of an infected cell by another hepatopancreatic cell, but infiltration of the epithelium of infected tubules by hemocytes in response to infection has not been reported with any of these baculoviruses.

Patent infections of BP and MBV can be identified with the light microscope by presence of typical tetrahedral or spherical occlusion bodies, respectively, in fresh squashes of minced hepatopancreas. Final diagnosis depends on finding greatly hypertrophied hepatopancreatic nuclei with marginated chromatin in tissue sections, together with occlusion bodies in the case of BP and MBV (Couch, 1974a, b; Sano et al., 1981; Lightner et al., 1983b). Grossly, the hepatopancreas of BMNV-infected P. japonicus is opaque and white, and postlarvae infected with BMNV and MBV tend to be smaller than normal and to grow more slowly (Sano et al., 1981; Lightner et al., 1983b).

Larval and postlarval stages of $P$. japonicus are most susceptible to BMNV, and BP causes greater mortality in larvae than in later stages of American penaeids (Sano et al, 1981; Couch, 1978). Postlarvae, juveniles, and adults of $P$. monodon are attacked by MBV. Lightner \& Redman (1981) and Lightner et al. (1983b) did not investigate larvae, but note that although larval culture and diseases of $P$. monodon have been widely studied, a disease similar to MBV disease has not been reported in larvae (nor was it reported in later stages prior to the papers by Lightner and coworkers).

The host range of BP is broad; five species of commercial North and South American Penaeus have been found infected (Couch, 1981; Lightner et al., 1983b). MBV will infect Penaeus merguiensis, but principally causes disease in $P$. monodon. MBV apparently will not infect Penaeus stylirostris or Penaeus californiensis, the other species tested (Lightner \& Redman, 1981). Host range of BMNV has not been studied.

BMNV can be transmitted to postlarval $P$. japonicus by feeding of infected tissue or by adding semi-purified virus to the water (Sano et al., 1981). Presumably BMNV and the other viruses are naturally transmitted horizontally in the same way. Mode of transmission from brood stock to offspring is unknown.

MBV in $P$. monodon becomes patent about the 20th to 30th day of the postlarval stage, and in one epizootic cumulative mortality was about $70 \%$. The epizootic studied ran its course in 210 days, but moderate infections were still present at 233 days 
(Lightner et al., 1983b). Sano et al. (1981) reported a cumulative mortality of $98 \%$ in $P$. japonicus by the 20th postlarval day during an epizootic of BMN at a larval-rearing facility in Japan.

Geographic range of the three viruses is not known. BP occurs in the Gulf of Mexico and probably the same virus has been found at shrimp culture facilities along the west coast of South and Central America (D. V. Lightner, pers. communication). Populations of $P$. monodon infected with MBV all came originally from Taiwan or the Philippines, but this shrimp species has a very wide distribution in the Pacific and Indian Oceans, and nothing is known about disease in populations from other areas (Lightner et al., 1983b). BMNV has been reported only from shrimp-rearing facilities in southern Japan (Sano et al., 1981).

Stressors enhance prevalence and severity of baculovirus infection. Crowding or exposure to sublethal amounts of PCBs (polychlorinated biphenyls) increases prevalence of BP in American penaeids (Couch, 1974b; Couch \& Courtney, 1977). Crowding, poor environmental conditions, and epizootics of shell disease, generalized bacterial infection, and fouling organisms increase both prevalence and mortality in $P$. monodon infected with MBV (Lightner et al., 1983b). Treatment of affected $P$. monodon populations with antibiotics, and with chemicals that reduce fouling, effectively increases the numbers of shrimp that survive viral infection.

BMN is an important cause of mortality in some larval-rearing facilities in southern Japan. Epizootics occur almost on a yearly basis, and can result in such severe mortality that it is impossible for the rearing facility to supply culture farms with postlarval shrimp (Sano et al., 1981). Lightner et al. (1983b) consider that MBV disease can cause serious losses in compromised populations, particularly in the younger stages. Under favorable culture conditions fewer mortalities occur, and only low grade infections with MBV can be detected. BP or a similar virus causes mortalities in larvae and postlarvae of $P$. vannamei in culture facilities on the west coast of Central America and Ecuador (D. V. Lightner, pers. communication).

I HHN virus of shrimp. Infectious hypodermal and hemopoietic necrosis, although newly discovered, has been extensively studied by D. V. Lightner and coworkers at the Environmental Research Laboratory (ERL), Marine Culture Facility (University of Arizona), Oahu, Hawaii. Because the Hawaiian Islands support only a small offshore fishery for Penaeus marginatus, all shrimp species being cultured at the ERL facility are imported. Further, the State of Hawaii requires that stock from new sources undergo quarantine. Therefore, viral diseases found in ERL stock can be considered exotic in origin. IHHNV caused disease in three species being cultured at the ERL facility. Penaeus stylirostris, the Pacific blue shrimp, was most affected; Penaeus monodon, the giant Indo-Pacific tiger prawn, was less affected; and Penaeus vannamei, the Pacific white shrimp, usually had inapparent infections (Lightner et al., 1983d).

IHHNV attacks principally tissues of mesodermal and ectodermal origin, but it will also infect endodermally derived tissues. Necrotic tissues contain hypertrophied nuclei with marginated chromatin and eosinophilic Cowdry Type A inclusions (Fig. 4). Lightner et al. (1983a) recommend use of an acetic acid-containing fixative for best demonstration of the Cowdry Type A inclusions. The general epidermis and hemopoietic tissue are especially prone to infection and necrosis (Lightner et al, 1983c). IHHNV rarely causes lesions discernible by light microscopy in the midgut, its ceca, or the hepatopan- 
creas, but typical IHHN Cowdry Type A inclusions have been observed in hepatopancreatic epithelial cells of experimentally exposed P. stylirostris (D. V. Lightner, pers. communication). Bell \& Lightner (1983) found that gill epithelia and the ventral nerve cord of $P$. stylirostris were significantly more severely infected than the same tissues of $P$. vannamei. Infection rates in other tissues of the two species were similar, but there was a suggestion that the antennal gland of vannamei was more heavily infected than that of stylirostris.

Hemocytic reaction to presence of necrotic tissue, and perhaps to presence of virus, occurs in IHHN; melanization and nodule formation take place also. Fixed phagocytes (probably mainly in the heart) and nephrocytes of the gill and other areas contain large cytoplasmic inclusions in recovering animals. Apparently recovery depends in part on the ability of the shrimp to sequester and make innocuous the necrotic virus-containing tissues and disseminated necrotic material that might or might not contain active virus. Stem cells of the hemopoietic tissue undergo rapid division during recovery, thus augmenting their depleted numbers and replacing hemocytes destroyed by the virus and used up in defense reactions.

Grossly, severely infected shrimp have focal melanized areas in and under the gill epithelium and general epidermis. Abdominal musculature is often white and opaque. The cuticle is soft, apparently because premolt animals are unable to complete the molting process, or if they do, are unable to progress past the early postmolt stage (Lightner et al., 1983a). Behavior also differs from normal. Acutely infected $P$. stylirostris rise slowly to the surface, roll over when near or at the surface, then cease movement of the appendages and sink slowly to the bottom. This process is repeated until they die, usually within 4 to $12 \mathrm{~h}$. Infected $P$. vannamei do not exhibit this behavior. Bell \& Lightner (1983) believe the lessened necrosis of the gill epithelium and ventral nerve cord in vannamei, which would indicate better respiration and nervous control, is the probable reason for lack of that behavioral sign.

All the gross signs exhibited by infected shrimp, with the probable exception of the "rolling" behavior of $P$. stylirostris, can be seen in other diseases. Diagnosis of IHHN depends on finding Cowdry Type A inclusions in tissue sections (Lightner et al., 1983a). If populations suspected of being infected are maintained under crowded conditions, prevalence and severity of infection are enhanced, making diagnosis easier. Because vannamei usually has inapparent infections, the following bioassay is useful for demonstrating IHHNV in a population of that species. P. stylirostris of an appropriate size and from a population known to be free of IHHN are either placed together with the group of $P$. vannamei or tissues from the vannamei are fed to the group of stylirostris. If IHHNV is present in the group of vannamei, readily diagnosable disease occurs in the stylirostris within 10 days (Lightner et al., 1983a).

Juveniles of $P$. stylirostris are the primary victims of IHHN. Size and weight are more important than age for disease induction, and IHHN usually appears in shrimp weighing from 0.05 to $1.00 \mathrm{~g}$. If members of a population of stylirostris imported as postlarvae surpass, on an average, the weight of $2 \mathrm{~g}$ without undergoing noticeable mortality or showing signs of IHHN, the population can be considered free of the disease. Because postlarvae of stylirostris newly introduced into the ERL facility did not show signs of IHHN, and epizootics are apparently initiated only after a certain amount of growth and maturation has occurred, it is possible that infections are usually inapparent in the 
younger stages, even though infection must occur at a very early age, or transovarially (Bell \& Lightner, 1983; Lightner et al., 1983a, d).

Sixteen populations of $P$. stylirostris, received as postlarvae in Hawaii from brood stock originating in Central and South America, underwent lethal epizootics of IHHN, with cumulative mortalities typically exceeding 80 to $90 \%$ (Lightner et al., 1983c). A population of $P$. monodon exposed to infected stylirostris as adults contracted IHHN, and IHHN was diagnosed as cause of death in other IHHNV-exposed $P$. monodon from the facility that underwent steady, but not marked, mortality over a period of several months (Lightner et al., 1983c). $P$. vannamei received as postlarvae from Central and South America and reared at the time of the IHHN epizootics also were infected with IHHNV. These populations underwent chronic low mortality, and although lesions in moribund shrimp were typical of IHHN, Cowdry Type A nuclear inclusions were seldom present (Bell \& Lightner, 1983).

IHHNV can be transmitted by injection of suspensions of infected tissues or semipurified virus, per os, by direct contact with known infected shrimp, and by indirect contact through water (Lightner et al., 1983d). In nature transmission probably occurs per os and by contact with virus-containing water or substrate. It was mentioned earlier that the epithelium of the antennal gland is infected (Bell \& Lightner, 1983). Virus, if sloughed with necrotic epithelial cells into the lumen of the gland, would eventually exit via the excretory pores, and transmission from living shrimp could be effected by this route. Because the hepatopancreas is infected, virus probably also exits via the feces. There is also the possibility that virus might pass through the cuticle of infected fore- and hindgut, or be shed into the gut lumen in these areas by molting shrimp (D. V. Lightner, pers. communication). In the groups of shrimp studied, transmission from parents to offspring had occurred before shipment of postlarvae to Hawaii (Lightner et al., 1983c). Whether this transmission was truly vertical, or through external contamination of ova and larvae, is not known.

Epizootics of IHHN are explosive and relatively brief. The mortality rate diminishes markedly about the 20th day after the first mortalities occur. During the final stages of an epizootic, surviving shrimp are lethargic, feed poorly, exhibit poor growth and poor resistance to stress. There is a tendency for severe surface fouling. Numerous melanized areas and nodules can be observed grossly in the tissues.

$P$. stylirostris and $P$. vannamei are native to the Pacific coast from Mexico to Peru. IHHNV has been detected histologically in tissue samples from stylirostris from culture facilities in Tahiti, Ecuador, Israel, and the Cayman Islands. IHHNV was found in tissues of $P$. vannamei from the Cayman Islands and in $P$. monodon from Ecuador, Guam, Tahiti, and the Philippines. Infected populations of stylirostris at the ERL facility came from Ecuador, Florida (Panamanian-derived brood stock), and Costa Rica. Infected P. vannamei populations present in the Hawaiian facility at the time of the epizootics were from Ecuador, Honduras, and Costa Rica. IHHN did not occur in one stylirostris population derived from Mexican brood stock (originally from Panama) maintained in quarantine at the University of Arizona's Sonora, Mexico facility (Bell \& Lightner, 1983; Lightner et al., 1983d). These authors suggest that species like $P$. vannamei, which usually have inapparent infections, might act as carriers to susceptible species, such as stylirostris and monodon, being reared in the same culture facility. Lightner and coworkers point out that the danger goes beyond the catastrophic epizootics that can 
occur in stylirostris. There is potential for spread of undetected virus to shrimp culture facilities throughout the world, and it is not known whether IHHNV will infect species of penaeids other than the three studied.

$\mathrm{HLV}$ in the blue crab. The herpeslike virus of Callinectes sapidus was first found in moribund juvenile and mature wild crabs from Chincoteague Bay, Virginia, and later in small juvenile crabs, both wild and captive, from Assawoman Bay, Delaware (Johnson, 1976a, 1978). Prevalence in a natural population of juvenile blue crabs can be $13 \%$ (Johnson, 1983). Infected crabs appear normal until shortly before death, when they become inactive and cease feeding. Hemolymph withdrawn from terminally infected crabs is an opaque, chalky white and has lost the capacity to gel. Crabs injected with hemolymph from moribund HLV-infected crabs die in 30 to 40 days (Johnson, 1978), but natural infections may take much longer before causing death. Moderate to heavy HLV infections were found in juvenile crabs that had been kept in the laboratory for 50 days in separate containers with separate water supplies, showing that virus was present before capture (P. T. Johnson, unpublished data). HLV caused an epizootic with a high mortality rate in juvenile crabs held in separate containers but with a common water supply, indicating that HLV disease is highly infectious by the water route (N. C. Biddle, pers. communication).

Some HLV-infected crabs are also infected with RhVA, including infection of the same cell, and an unusually heavy infection with Baculo-A (of the hepatopancreas) was found in one HLV-infected crab (P. T. Johnson, unpublished data).

HLV infects hemocytes and occasionally is found in hemopoietic cells, and probably in connective-tissue cells and epithelial cells of the gill. Infected nuclei are greatly hypertrophied and either contain Feulgen-positive granules or are homogeneous and faintly to deeply Feulgen positive. Infected nuclei may contain large Feulgen-negative inclusions, and similar inclusions regularly occur in the cytoplasm. The cytoplasm of severely infected cells is reduced to a thin rim, and release of virus is by lysis of the nucleus. Hemolymph of a terminally infected crab is filled with free virus and granular material apparently derived from the breaking up of the cytoplasmic and nuclear inclusions. Fixed phagocytes interstitial in the hepatopancreas are greatly swollen, filled with a homogeneous, slightly Feulgen-positive material, and are often necrotic. EM examination shows that the homogeneous material is a mixture of viral particles and granular material probably originating from the hemolymph. Whether HLV-infected crabs ever recover is unknown. Death probably occurs because of hemocyte dysfunction and loss.

Final diagnosis of HLV disease depends on finding typical infected cells in paraffinembedded tissue sections, but reasonably firm diagnosis of terminal infections can be made on the basis of the hemolymph being chalky white and non-gelling.

Diseases of crabs caused by reolike viruses. The P virus of Macropipus depurator from the French Mediterranean coast is usually associated with the $S$ virus, and lesions produced in doubly infected crabs might be due to both viruses. External signs of disease appear to be the same whether crabs have single or double infections. Natural disease and disease experimentally induced by injection of purified virus are characterized by increasing paralysis (Bonami, 1973; Bonami et al., 1976). Naturally infected crabs also exhibit browning of the exoskeleton and lack of molt (Vago, 1966), signs not seen in experimental infection because death comes so rapidly. 
On injection of purified virus, $60 \%$ of the crabs have trembling of the limbs within 6 days, followed by general paralysis and a mortality of 70 to $80 \%$ in 9 days (Bonami et al., 1976). In experimentally infected crabs the hemal spaces of the hepatopancreas are obliterated by necrotic connective-tissue cells containing paracrystalline, angulate arrays of virus that are visible with the light microscope. Hemocytes and connective tissues of the gill and surrounding the gut are also infected. Blood-vessel endothelia are infected, as shown by an electron micrograph in Bonami et al. (1976). Other tissues and organs, including especially hemopoietic tissue and nervous tissue, apparently were not investigated by these authors. Diseased crabs with P-virus infections were found in the natural environment, but there is no information on prevalence in wild populations.

Gross signs of RLV + RhVA infection in Callinectes sapidus closely resemble those caused by $\mathrm{P}$ virus in $M$. depurator; additionally, withdrawn hemolymph will not gel. RLV + RhVA, often in the same cell (Fig. 5), infect and cause necrosis of many mesodermally and ectodermally derived tissues, particularly hemopoietic tissue, hemocytes, endothelia of blood vessels, epidermis, and glia of the central nervous system. Paralysis occurs due to destruction of the glia (Fig. 6), and death is probably due to the combined effects of glial necrosis and massive loss of hemocytes. Injection of infected hemolymph into normal crabs can cause death in 3 days; feeding of infected tissues results in death in 12 to 35 days (Johnson, 1977, 1983).

The original group of crabs infected with RLV + RhVA were juveniles from

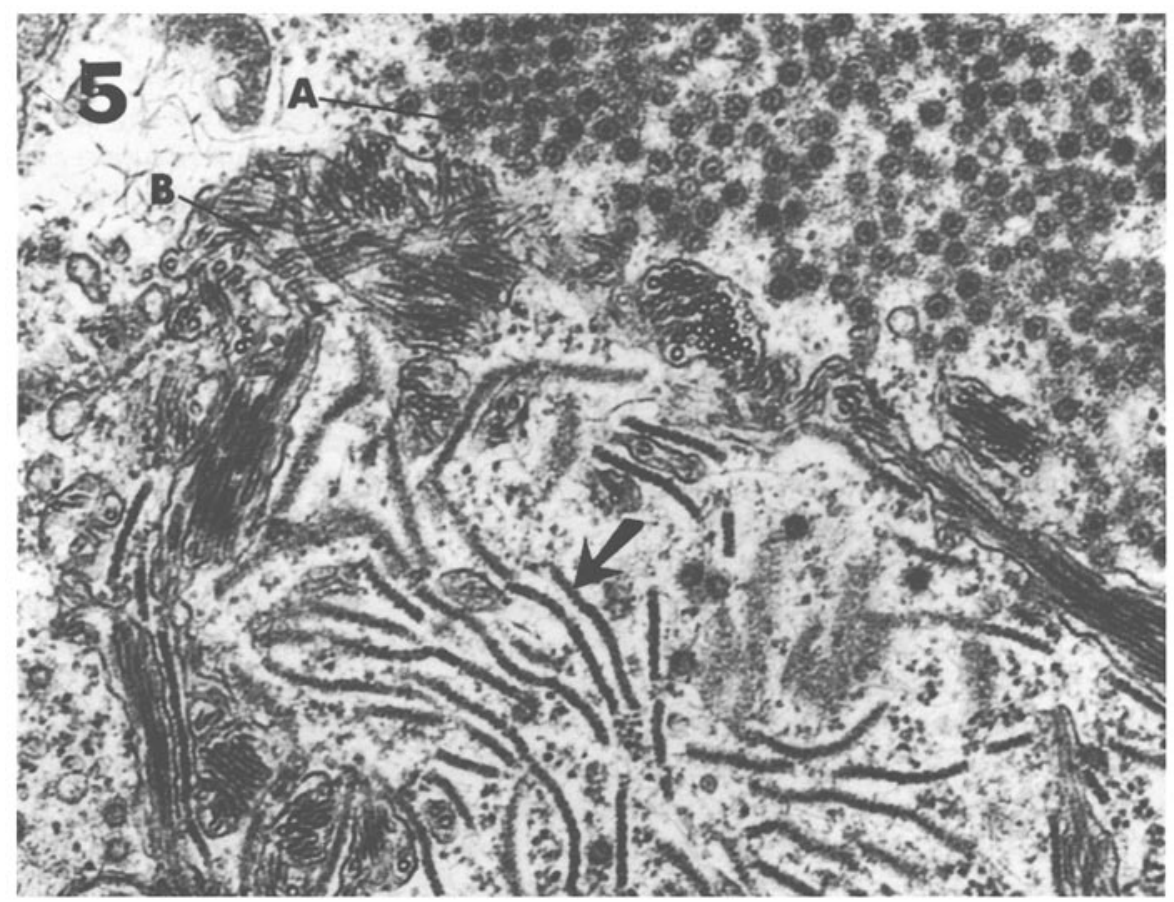

Fig. 5. Electron micrograph of RLV in the cytoplasm, and RhVA in the endoplasmic reticulum, of a single cell from Callinectes sapidus. The sinuous strands (arrow) are associated with development of RLV. $A=$ RLV, B $=$ RhVA, $27,720 \mathrm{X}$ 


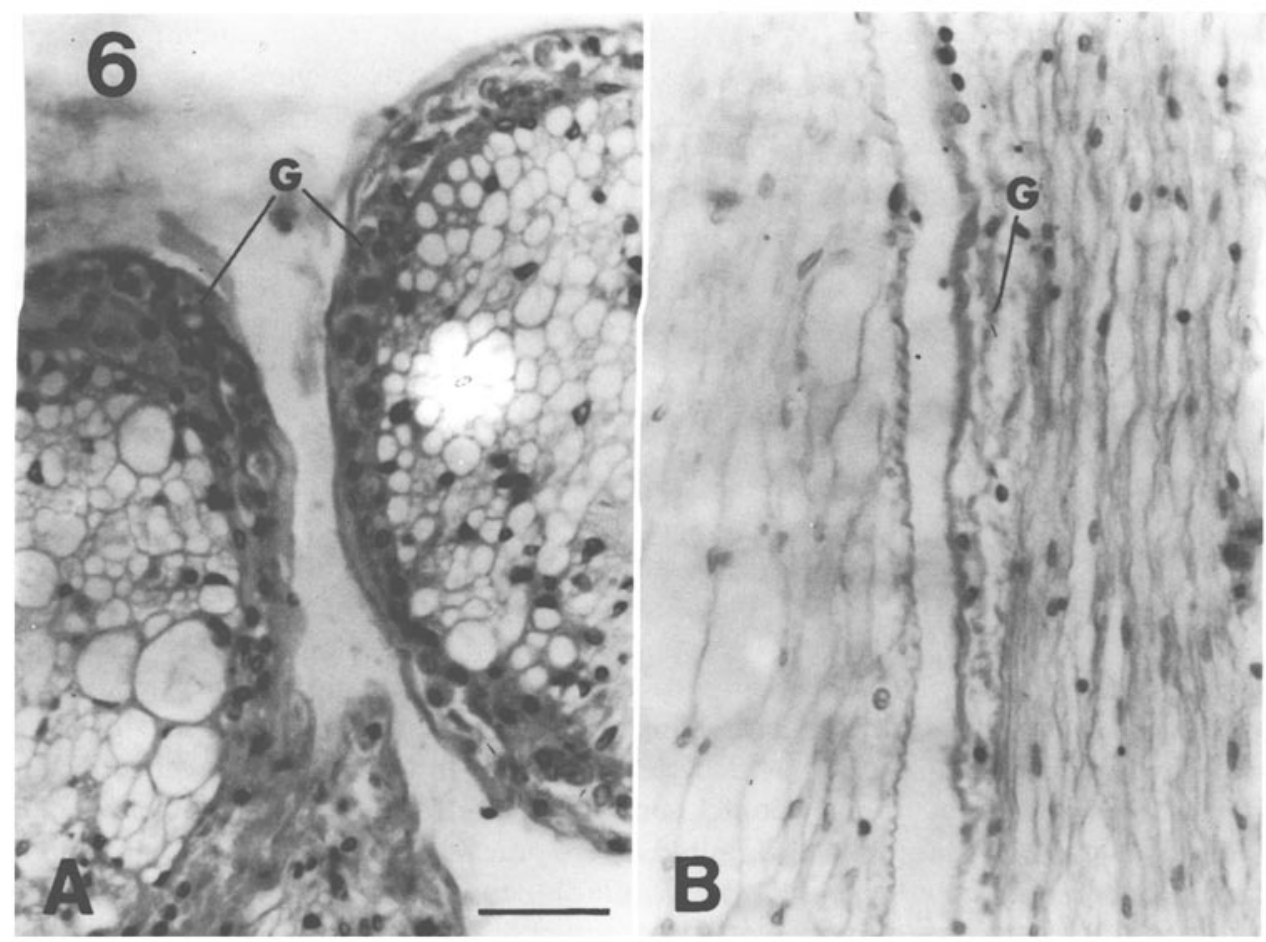

Fig. 6. Neuroglia of virus-infected Callinectes sapidus. A: Cross section of large nerves in an RLV + RhVA-infected crab; hemocytes are present in the necrotic glial areas. B: Longitudinal section of similar nerves in a CBV-infected crab; the glia are normal. $G=$ glia, alcian blue-nuclear fast red stained, bar $=20 \mu \mathrm{m}$

Chincoteague Bay, Virginia. The crabs began dying 14 days after collection from the wild, and the last crab died on the 35th laboratory day. Many experimentally and naturally infected crabs had one or more other viruses: Baculo-A, Baculo-B, and EHV. However, gross signs of disease and major lesions in the tissues were similar in all these crabs. RLV + RhVA have been found repeatedly in crabs collected from Chesapeake and Chincoteague Bays, Maryland and Virginia, but recognizable gross signs occur only after several days in the laboratory. This perhaps is because crabs whose disease has progressed to the paralytic stage are rapidly removed by predators, including other blue crabs, and thus are not readily available for capture.

Effective hemocytic response to RLV + RhVA does not occur. Fixed phagocytes take up virus, but are often hypertrophied and necrotic. Granulocytic hemocytes invade infected hemopoietic tissue, but perhaps in response to necrotic tissue rather than to virus. Since the two viruses infect hemocytes, these cells cannot produce effective cellular reaction to them. However, all crabs are not killed by experimentally inoculated virus, and mechanisms that might lead to recovery or refractoriness to infection have not been investigated. Particularly, crabs have not been examined during prepatent stages of experimental infection.

The characteristic paralysis and non-gelling hemolymph are presumptive signs of 
disease due to RLV + RhVA, but final diagnosis depends on a combination of light microscopy and EM. If angulate, basophilic, Feulgen-negative, cytoplasmic inclusions are present in hemocytes and hemopoietic tissue, light microscopy is sufficient for diagnosis. Other viruses (and sometimes RLV) can produce similar but rounded cytoplasmic inclusions. In these cases, EM examination is necessary for diagnosis.

Diseases of crabs caused by bunyalike viruses. The $S$ virus of Macropipus depurator is usually associated with the $\mathrm{P}$ virus in natural infections, but single infections do occur in nature (Bonami \& Vago, 1971). When purified virus is injected into normal crabs, it causes 70 to $80 \%$ mortality in 15 to 20 days. Infected animals become weak by 10 days, and the only outward sign is increasing weakness. Hemocytes are infected by $S$ virus. They become vacuolated and have only limited pseudopodial extension. Cardiac tissue of an unspecified type is also infected (Bonami et al., 1971; Bergoin et al., 1982).

CHV of Carcinus maenas was isolated from a single wild crab collected at Roscoff, France, and all information on CHV disease is based on experimental infections. CHV apparently occurs only in hemocytes, especially granulocytes, and produces a defect in aggregation of hemocytes. Hemocytes from normal crabs immediately begin to form large aggregations in withdrawn hemolymph. (The liquid phase of Carcinus hemolymph gels slowly and incompletely.) Hemocytes from CHV-infected crabs never form large aggregations and often do not contact each other at all (Bang, 1971; Hoover \& Bang, 1976; Hoover, 1977; Bang, 1983). Limited aggregation is apparently dependent on the small number of circulating hemocytes available, and Hoover (1977) found numerous stationary aggregations of hemocytes in the hemal sinuses of sectioned tissues. She postulated that infection produced increased adhesiveness, which caused hemocytes to stick to each other and to the walls of the hemal sinuses, thus dropping from the circulation. Bang (1983) suggested that abnormalities of the cells themselves may be partially responsible for lack of aggregation, although they appear to extend pseudopodia like normal cells. Although virus has not been seen in gonadal cells, Hoover reported that degeneration and hemocytic infiltration occur in ovaries of infected females. Many of the infiltrating hemocytes are infected with virus. CHV usually does not cause death, and crabs regain clotting ability in 5 to 10 days, but virus is still present in some of these animals (Bang, 1971, 1974). Dilution of hemolymph taken early in infection increases the time before an injected crab shows lack of clotting ability. The situation is reversed in later infection, which suggested to Bang $(1974,1983)$ that autointerference or an interferonlike substance might be responsible.

$\mathrm{CBV}$ in blue crabs. This picornalike virus was discovered in a captive group of about 200 juvenile blue crabs taken from Chesapeake Bay. It has not been detected in wild crabs (Johnson, 1978, 1983). Typically, CBV infection is focal. Tissues of ectodermal and mesodermal origin are attacked. Putative neurosecretory cells, other types of nerve cells, the retina, epithelia of fore- and hindguts, bladder and gill epithelia, and the general epidermis are commonly infected. Hemocytes and hemopoietic tissue are less often attacked, and glia of the nervous system, muscle, and the midgut epithelia are not affected (Fig. 6). Infected cells are usually hypertrophied and the cytoplasm is filled with Feulgen-negative homogeneous material consisting almost entirely of virus (Fig. 7). Although infection is often focal, the gill epithelium may be almost completely infected, and destruction of the entire retina is common. 


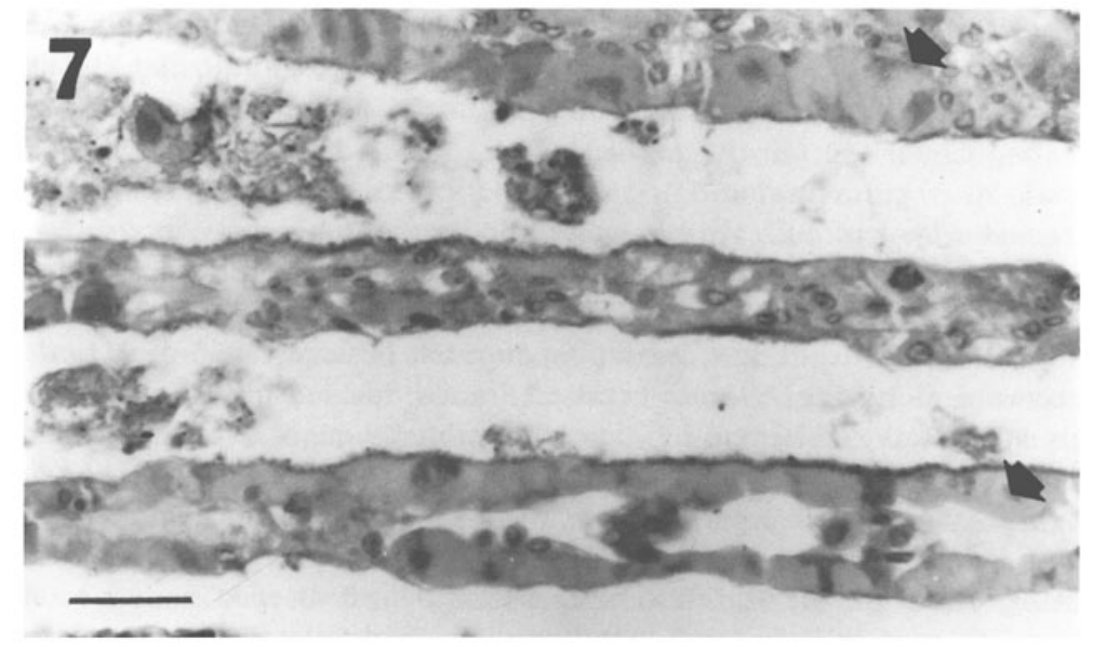

Fig. 7. Gill lamellae of a CBV-infected Callinectes sapidus. Middle lamella is normal. Epithelial cells of the upper and lower lamellae are hypertrophied and heavily infected with virus (arrows). Alcian blue-nuclear fast red stained, bar $=20 \mu \mathrm{m}$

Abnormal behavior is exhibited by infected crabs. They may assume a head-down position, swim in a disoriented fashion, and perform erratic movements. Blindness is common. These signs may be present for a month before death, and entire course of the disease takes up to 2 months. Because tissues attacked differ among crabs, and infection tends to be focal, prolonged disease may be due to vital centers not being destroyed until late in disease. Death may be due to respiratory insufficiency, or destruction of vital nervous centers and neurosecretory cells.

Host response to CBV infection seems to be lacking except that podocytes of the gill and antennal gland contain dense Feulgen-negative inclusions that might be due to uptake of virus or products of viral infection. Visual evidence of intact virus within the podocytes was lacking, but insufficient material has been examined with EM to allow a definite statement to this effect (P. T. Johnson, unpublished data).

Preliminary diagnosis of CBV disease can be made on the basis of behavioral signs and presence in target tissues of characteristically hypertrophied cells with dense Feulgen-negative cytoplasm. Final diagnosis depends upon demonstration of virus by EM.

Octopus iridovirus diseas e. Rungger et al. (1971) estimate that at the time of their research up to $8.4 \%$ of the Octopus vulgaris population of the Bay of Naples may have been suffering from disease caused by the iridovirus. The disease always ends fatally. Gross signs are presence of subdermal edematous tumors, first seen in tentacles and then in the ventral parts of the mantle and in the siphon. When first visible, tumors are about $1 \mathrm{~mm}$ diameter but may measure 5 to $10 \mathrm{~mm}$ in advanced cases. Tumors lie within lysed and lysing areas of muscle and contain numerous particles of virus, which may be surrounded by a multilayered membranous envelope. As infection progresses, the animal becomes sluggish and may refuse to feed, leading to death by starvation. More often, the octopus eats away affected parts, including whole tentacles and some- 
times the ventral part of the mantle, Rungger and coworkers assume death is due to either or both self mutilation and viral infection. Disease is chronic and its course from first appearance of the tumors to death was estimated to be 3 to 5 months in captive animals.

Iridolike viruses in diseased oysters. The adult and larval oysters found infected with iridolike viruses came from populations that were suffering mortalities, but the place of the viruses in total pathogenesis is still uncertain. The first reports of iridolike-virus infection, by Comps et al. (1976) and Comps \& Duthoit (1976), concerned Portuguese oysters, Crassostrea angulata. During 1966-1969 serious mortalities occurred along the Atlantic coast of France due to "gill disease", which was tentatively attributed to infection by a putative protist thought to be related to Labyrinthulales, and named Thanatostrea polymorpha (Franc \& Arvy, 1969). These epizootics were followed by devastating mortalities in 1970-1973. Culture of C. angulata collapsed, due to the two epizootics, and this species was replaced by imported Japanese oysters, Crassostrea gigas, which appeared to be resistant to "gill disease".

The epizootics of "gill disease" involved necrosis of gills and palps, but gross signs associated with sick oysters in the mortalities of 1970-1973 were apparently lacking. Sick oysters were merely noted as being weak. EM study of gills from oysters suffering from "gill disease" revealed iridolike virus in inclusions in giant cells in the necrotic areas (Comps \& Duthoit, 1976). These authors noted similarities to the lesions in fish caused by lymphocystis virus. Comps et al. (1976) studied material from the 1970-1973 epizootics. Iridolike virus was present in abnormal cells with fuchsinophilic inclusions, that occurred throughout the oysters, and appeared to be hemocytes. These cells were regularly seen in oysters collected during the course of the epizootics. By size and developmental characteristics, the virus is very similar to the one found in oysters with "gill disease", but it must be remarked that the cells attacked appear to be different, based on the information given in the papers by Comps \& Duthoit (1976) and Comps et al. (1976). The latter authors believe the iridolike virus was the cause of the 1970-1973 epizootics, but that a parasitic etiology of the earlier "gill disease" epizootics has not been ruled out.

In 1977 mortalities occurred in certain populations of Crassostrea gigas imported earlier to replace $C$. angulata. An iridolike virus was found in connective-tissue cells of dying oysters (Comps \& Bonami, 1977). Although slightly larger than virions found in $C$. angulata collected during the "gill disease" of 1966-1969 and the 1970-1973 epizootics, all the viruses are similar in development and morphology. Comps \& Bonami concluded that these viruses probably are all the same species. They further noted that the presumed resistance of $C$. gigas to the iridolike virus originally found in $C$. angulata needs to be reassessed.

A smaller iridolike virus has been found in larvae of $C$. gigas. In 1978, Leibovitz et al. described histopathology and course of mortalities they studied over a 3-year period in larvae of $C$. gigas being reared in a hatchery in the State of Washington. A similar condition was found in larvae at three other Washington State hatcheries, and in wild larvae collected up to 400 shoreline miles distant from the primary study site. The condition involved progressive velar necrosis associated with minute zoosporelike bodies, which increased in number with increased necrosis of the velum. Many spherical bodies, resembling fungus, appeared in the stomach, and these, together with copious 
mucus, were continually regurgitated. The regurgitated material further damaged the velum mechanically, velar cilia detached, and generalized necrosis of mantle and velum was followed by necrosis of the other soft tissues. On the basis of light microscopy, the condition was suspected of being a fungal disease. During EM investigation of velar lesions, Elston (1979) found an iridolike virus in degenerating cells of the velar epithelium of hatchery-reared larvae. EM examination failed to demonstrate zoospores in velar tissues. The objects that appeared like zoospores with the light microscope were irregular electron-opaque objects not resembling microorganisms (Elston, 1980). These objects, and lesions associated with them, were much more numerous than the iridovirus. The spherical bodies in the stomach of diseased larvae were identified as a fungus resembling Hyalochlorella marina, and the regurgitation of stomach contents is apparently due to the excessive quantity and size of the gastrointestinal contents (Elston, 1980). Later, study of similar velar lesions in larval C. gigas from Tasmania showed that the zoosporelike objects are transformed and necrotic mitochondria (Leibovitz \& Comps, 1982). These authors state that the type of necrosis exhibited in the velar mitochondria is known to occur through failure of osmoregulatory mechanisms and toxic insult to the cell, and that these are important responses to adversely altered aquatic environments. Whether the iridolike virus was able to establish patent infection because of the stressed condition of the larvae, and whether it contributed to that stress, deserve further study.

\section{DISCUSSION}

If a distinction is made between investigation of disease in its broad sense on the one hand, and discovery, isolation, and identification of viruses on the other, certain conclusions can be drawn. Studies of viral disease in cultured shrimp involve animals of known history maintained in controlled environments, and knowledge of other disease-causing agents and their effects on captive penaeid shrimp is considerable. Firm understanding of diagnosis of shrimp viral disease, pathogenicity of the viruses, methods of transmission, and the influence of biotic and abiotic stress is not an impossible goal. Good progress is being made on identification of some viruses of other marine invertebrates, but information on diseases caused by these viruses is anecdotal or has depended on studies of wild-caught animals of unknown history. Some subjects of disease studies were already virus infected before experimental exposure to a different virus (Johnson, 1983). If it is hard to assess most crustacean viruses as primary disease producers, assessment of mollusk viruses from that standpoint is even more difficult. Mollusk viruses strongly associated with disease states have not been isolated or transmitted experimentally (excepting, possibly, the putative virus considered by Oprandy et al. [1981] to be the etiologic agent of molluscan hemopoietic neoplasms). The iridovirus of octopus and herpeslike virus of oysters do appear to be associated with diseases that are dependent on the virus alone or on the virus plus a known physical stressor (Rungger et al., 1971; Farley et al., 1972). Identification and disease-causing propensities of iridoviruses found in diseased larvae and adults of oysters need further study.

In some instances it is not clear in a report whether virally diseased animals were taken from the natural environment or whether disease appeared only after capture (Table 3). Several of the viruses cause disease when experimentally transmitted to healthy animals. One must keep in mind that stress may precipitate disease in virally 
infected captive animals and that experimental transmission often exposes animals to more virus and by different routes than would occur in nature. From the standpoint of disease in aquaculture, these distinctions perhaps are mainly of academic interest, but they assume importance if one wishes to understand viral disease in natural populations.

Simultaneous presence of two viruses in wild or captive diseased insects is not uncommon (Vago, 1963). Occurrence of two or more viruses in diseased crabs in laboratory populations is also not uncommon and is a regular or constant feature of three disease syndromes. Excepting $\mathrm{P}+\mathrm{S}$ viruses and F-N viruses of Macropipus depurator, and RLV + RhVA of Callinectes sapidus, we cannot predict whether or not multiple viral infection is likely to occur frequently in nature. Multiple infection in laboratorymaintained and experimentally infected crabs proves that such infection is biologically possible and theoretically it indicates that multiple viral infection might be a threat in crustacean aquaculture.

With exception of shrimp and oyster larvae, very young juvenile stages or larvae of marine invertebrates have not been examined for presence of viruses. The best known invertebrate viruses, those of holometabolous insects, cause disease much more frequently in larvae than in adults - a tendency so accepted by insect pathologists that reviewers of viral disease in insects often neglect to specify the fact (Steinhaus, 1963; Cantwell, 1974). IHHNV of Penaeus stylirostris apparently occurs as a latent virus in larvae, with disease manifested in the postlarval stage (Lightner et al., 1983c), but BMNV of Penaeus japonicus causes disease in larvae as well as postlarvae (Sano et al., 1981). Determination of the most susceptible stages to other marine invertebrate viruses is yet to be accomplished, and whether transovarial transmission occurs with any of the viruses is unknown.

The lack of reports of viruses from lobsters, and crabs of the genus Cancer, is interesting. These groups contain very important commercial species; they are often held in impoundments, and their diseases and parasites have been investigated in many localities over a considerable number of years. It may be that the large, mature animals forming the fisheries are less susceptible to viruses, and that surveys of younger animals would reveal viral infections. For example, viruses of the blue crab, another valuable and much studied commercial species, were unknown until juvenile crabs were investigated.

Studies on host range of marine invertebrate viruses are confined to those of penaeid shrimp and the birnaviruses cultured from bivalve and gastropod mollusks. IHHNV of shrimp infects at least three species of Penaeus, but pathogenicity differs markedly in the three in which it has been studied. The birnaviruses from mollusks appear to have a rather broad host range, and all are considered strains of IPNV. Their capacity to cause disease in their invertebrate hosts is undecided, but infected mollusks might serve as reservoirs of IPNV for fish. That a picornalike virus of a parasitic isopod also infects its crab host might indicate that this virus has a broad host range, but could be a special instance that came about through the close association of a host and its parasite. The $P$ virus of Macropipus depurator and RLV of Callinectes sapidus are similar morphologically and developmentally, and non-occluded baculoviruses that infect hemocytes of C. sapidus and Carcinus maenas are similar in the same ways. The hosts are all portunid crabs, and it would not be surprising to find the related pairs of viruses to be closely related species or strains of the same species. Viruses have been studied mainly in the 
commercial or the larger species of decapod crustaceans and bivalve mollusks. We have little information on viral infections of other animals living in the same environments, that might be reservoirs or otherwise be involved in ecology of known viruses. Iridoviruses, with their often broad host ranges, are of special interest because iridolike viruses implicated in epizootics affecting cultured oysters might have alternate hosts in the same environments.

Latent viral infections and ones that are slow to develop into overt disease are a problem in shrimp culture. There are other viruses that might accidentally be brought in with introduced animals. For example, the considerable prevalence of HLV disease in blue crabs without external signs, and the ability of the virus to be waterborne suggest that HLV might easily be introduced inadvertently into virus-free populations by imported crabs kept in open systems.

\section{CONCLUSIONS}

That stress has been found to exacerbate viral prevalence and disease in marine invertebrates is not surprising; it does the same in vertebrate populations. As Overstreet (1978) says: ". . the most important factor in transforming an infection into a disease is stress." The documentation now available on effects of stress on viral disease (and on other diseases) of marine invertebrates will prove valuable to studies of the effects of pollutants or other man-made stressors on natural populations, and effects of various stressors in aquaculture. Important as stress is, it would be a mistake to assume all viral diseases of marine invertebrates are stress related. A virus introduced into populations lacking genetic resistance, as IHHNV of shrimp, is known to cause devastating mortalities, and HLV of the blue crab can have a relatively high prevalence in natural populations where stress does not seem to be a feature.

Knowledge gained in the past 10 years on viruses of cultured shrimp, most particularly the results of recent research by D. V. Lightner and coworkers, will prove to be of primary importance for our eventual understanding of viral disease in marine invertebrates, both cultured and wild. We are aware that disease-causing viruses are not necessarily host specific. We now know that a virus causing inapparent infection in one species can cause devastating disease in another. These facts can hardly be ignored when plans are made to introduce exotic species of marine invertebrates for contained or free culture.

Clearly, we know very little about viruses and viral disease in natural populations of marine invertebrates. Almost any research approach should yield valuable knowledge applicable to both artificial and natural environments. Among other subjects, we particularly need taxonomic studies to determine the identity or separateness of certain viruses infecting decapods and mollusks; studies on host range and relative pathogenicity in the hosts; studies on methods of transmission; and surveys of viral occurrence in natural communities of marine invertebrates.

Methods currently available for identification of marine invertebrate viruses are cumbersome, time-consuming, and sometimes of questionable accuracy. The need for cell-culture systems from both bivalve mollusks and decapod crustaceans that will support replication of the various viruses is a paramount concern (Johnson, 1983; Lightner et al., 1983a). Cell cultures would make possible many tests, including the 
determinations of CPE and production of large quantities of virus for determination of immunologic parameters of viruses and fluorescent antibody testing, etc, that are necessary for fast, simple, and accurate diagnosis. Until cell cultures are available, the studies suggested above will progress very haltingly.

Acknowledgements. Mr. C. Austin Farley, of my laboratory, shared with me his knowledge and hypotheses regarding invertebrate viruses, and reviewed the manuscript. Dr. Donald V. Lightner, Environmental Research Laboratory, University of Arizona, Tucson, Arizona, also reviewed the manuscript and generously made available to me copies of papers in press and data concerning his most recent experiments and observations on shrimp viruses. My thanks to both gentlemen.

\section{LITERATURE CITED}

Adams, J. R., Dougherty, E. M. \& Heimpel, A. M., 1980. Pathogenesis of rhabdoviruslike particles in the house cricket, Acheta domesticus. - J. Invertebr. Pathol. 35, 314-317.

Allen, T. C., 1972. Bacilliform particles within asters infected with a western strain of aster yellows. - Virology 47, 491-493.

Balouet, G., Poder, M. \& Cahour, A., 1982. Hyaline cell proliferation in Ostrea edulis L.: Histogenetic and oncologic approach. - Proc. int. Colloq. Invertebr. Pathol. 3, 268-270.

Bang, F. B., 1971. Transmissible disease, probably viral in origin, affecting the amebocytes of the European shore crab, Carcinus maenas. - Infect. Immun. 3, 617-623.

Bang, F. B., 1974. Pathogenesis and autointerference in a virus disease of crabs. - Infect. Immun. 9, $1057-1061$.

Bang, F. B., 1983. Crustacean disease responses. In: The biology of Crustacea. Ed. by A. J. Provenzano. Acad. Press, New York, 6, 114-153.

Bazin, F., Monsarrat, P., Bonami, J. R., Croizier, G., Meynadier, G., Quiot, J. M. \& Vago, C., 1974. Particules virales de type baculovirus observées chez le crabe Carcinus maenas. - Revue Trav. Inst. Pêch. marit. 38, 205-208.

Bell, T. A. \& Lightner, D. V., 1983. The penaeid shrimp species affected and known geographic distribution of IHHN virus. - Proc. Symp. warm water crustacean Aquacult. Brigham Young Univ., Laie, Hawaii. (In press).

Bergoin, M. \& Morel, G., 1978. Studies on three viruses of arachnids. - Proc. int. Colloq. Invertebr. Pathol. 2, 21-22.

Bergoin, M., Bonami, J.-R. \& Morel, G., 1982. Crab and spider viruses. - Proc. int. Colloq. Invertebr. Pathol. 3, 523-526.

Bonami, J.-R., 1973. Recherche sur la paralysie virale du Crustacé Décapode Macropipus depurator L. - Revue Trav. Inst. Pêch. marit. 37, 387-389.

Bonami, J.-R., 1976. Viruses from crustaceans and annelids: Our state of knowledge. - Proc. int. Colloq. Invertebr. Pathol. 1, 20-23.

Bonami, J.-R. \& Vago, C., 1971. A virus of a new type pathogenic to Crustacea. - Experientia 27, 1363-1364.

Bonami, J.-R., Vago, C. \& Duthoit, J.-L., 1971. Une maladie virale chez les Crustacés Décapodes due à un virus d'un type nouveau. - C. r. hebd. Séanc. Acad. Sci., Paris (D) 272, 3087-3088.

Bonami, J.-R., Veyrunes, J.-C., Cousserans, F. \& Vago, C., 1975. Ultrastructure, développement et acide nuclêique du virus $\mathrm{S}$ du crustacé décapode Macropipus depurator L. - C. r, hebd. Séanc. Acad. Sci., Paris (D) 280, 359-361.

Bonami, J.-R., Comps, M. \& Veyrunes, J.-C., 1976. Étude histopathologique et ultrastructurale de la paralysie virale du crabe Macropipus depurator L. - Revue Trav, Inst. Pêch, marit. 40, 139-146.

Bonnefoy, A. M., Kolenkine, X. \& Vago, C., 1972. Particules d'allure virale chez les Hydres. - C. r. hebd. Séanc. Acad. Sci., Paris (D) 275, 2163-2165.

Brock, J. A., Lighter, D. V. \& Bell, T. A., 1983. A review of four virus (BP, MBV, BMN and IHHNV) diseases of penaeid shrimp with particular reference to clinical significance, diagnosis and control in shrimp aquaculture. ICES 1983/Gen: 10/Mini-Symposium, 1-18.

Brown, R. S., 1980. The value of the multidisciplinary approach to research on marine pollution 
effects as evidenced in a three-year study to determine the etiology and pathogenesis of neoplasia in the soft-shell clam, Mya arenaria. - Rapp. P.-v. Réun. Cons. perm. int. Explor. Mer $179,125-128$.

Buchanan, J. S., 1973. Electron microscopic observations of virus-like particles in the digestive gland of a marine bivalve mollusc, Tellina tenuis (da Costa). - Proc. int. Colloq. Insect Pathol. microb. Control 5, 28 .

Buchanan, J. S., 1978. Cytological studies on a new species of rickettsia found in association with a phage in the digestive gland of the marine bivalve mollusc, Tellina tenuis (da Costa). - J. Fish Dis. $1,27-43$.

Buchanan, J. S. \& Richards, R. H., 1982. Herpes-type virus diseases of marine organisms. - Proc. R. Soc. Edinb. (B) 81, 151-168.

Cantwell, G. E. (Ed.), 1974. Insect diseases. Dekker, New York, 1, 1-300.

Chassard-Bouchaud, C. \& Hubert, M, 1975. Sur l'existence de vésicules de réticulum endoplasmique lisse dans l'organe Y de Carcinus maenas L. (Crustacé Décapode). - C. r. hebd. Séanc. Acad. Sci., Paris (D) 281, 707-709.

Chassard-Bouchaud, C., Hubert, M. \& Bonami, J.-R., 1976. Particules d'allure virale associées à l'organe Y du crabe Carcinus maenas (Crustacé Décapode). - C. r. hebd. Séanc. Acad. Sci., Paris (D) 282, 1565-1566.

Cole, A. \& Morris, T. J., 1980. A new iridovirus of two species of terrestrial isopods, Armadillidium vulgare and Porcellio scaber. - Intervirology 14, 21-30.

Comps, M. \& Bonami, J. R., 1977. Infection virale associée à des mortalités chez l'huître Crassostrea gigas Thunberg. - C. r. hebd. Séanc, Acad. Sci., Paris (D) 285, 1139-1140.

Comps, M. \& Duthoit, J. L., 1976. Infection virale associée à la maladie des branchies de l'huître portugaise Crassostrea angulata LMK. - C. r. hebd. Séanc. Acad. Sci., Paris (D) 283, 1595-1596.

Comps, M., Bonami, J. R.; Vago, C. \& Campillo, A., 1976. Une virose de l'huître portugaise (Crassostrea angulata LMK). - C. r. hebd. Séanc. Acad. Sci., Paris (D) 282, 1991-1993.

Cooper, K. R. \& Chang, P. W., 1982. A review of the evidence supporting a viral agent causing a hematopoietic neoplasm in the soft-shelled clam, Mya arenaria. - Proc. int. Colloq. Invertebr. Pathol. 3, 271-272.

Cooper, K. R., Brown, R. S. \& Chang, P. W., 1982a. The course and mortality of a hematopoietic neoplasm in the soft shell clam, Mya arenaria. - J. Invertebr. Pathol. 39, 149-157.

Cooper, K. R., Brown, R. S. \& Chang, P. W., 1982b. Accuracy of blood cytological techniques for the diagnosis of a possible hematopoietic neoplasm in the bivalve mollusc Mya arenaria. - J. Invertebr. Pathol. 39, 281-289.

Couch, J. A., 1974a. Free and occluded virus, similar to Baculovirus, in hepatopancreas of pink shrimp. - Nature, Lond, 247, 229-231.

Couch, J. A., 1974b. An enzootic nuclear polyhedrosis virus of pink shrimp: Ultrastructure, prevalence, and enhancement. - J. Invertebr. Pathol. 24, 311-331.

Couch, J. A., 1978. Diseases, parasites, and toxic responses of commercial penaeid shrimps of the Gulf of Mexico and south Atlantic coasts of North America. - Fish. Bull. U.S. 76, 1-44.

Couch, J. A, 1981. Viral diseases of invertebrates other than insects. In: Pathogenesis of invertebrate microbial disease. Ed. by E. W. Davidson. Allanheld, Osmun, Totowa, New Jersey, $127-160$.

Couch, J. A. \& Courtney, L., 1977. Interaction of chemical pollutants and virus in a crustacean: A novel bioassay system. - Ann. N. Y. Acad. Sci. 298, 497-504.

Devauchelle, G., 1977. Ultrastructural characteristics of an iridovirus from the marine worm Nereis diversicolor (O. F. Muller): Architecture of the virion and virus morphogenesis. - Virology 81, $237-246$.

Devauchelle, G. \& Durchon, M., 1973. Sur la présence d'un virus du type Iridovirus dans les cellules mâles de Nereis diversicolor (O. F. Muller). - C. r. hebd. Séanc. Acad. Sci, Paris (D) 277, $463-466$.

Devauchelle, G. \& Vago, C., 1971. Particules d'allure virale dans les cellules de l'estomac de la seiche, Sepia officinalis L. (Mollusques, Céphalopodes). - C. r. hebd. Séanc. Acad. Sci., Paris (D) 272, 894-896.

Dobos, P., Hill, B. J., Hallet, R., Kells, D. T. C., Becht, H. \& Teninges, D., 1979, Biophysical and 
biochemical characterization of five animal viruses with bisegmented double stranded RNA genomes. - J. Virol. 32, 593-605.

Dougherty, C., Ferral, J., Brody, B. M. \& Gotthold, M. L., 1963. A growth anomaly and lysis with production of virus-like particles in an axenically reared microannelid. - Nature, Lond. 198, 973-975.

Elston, R., 1979. Viruslike particles associated with lesions in larval Pacific oysters (Crassostrea gigas). - J. Invertebr. Pathol. 33, 71-74.

Elston, R., 1980. Ultrastructural aspects of a serious disease of hatchery reared larval oysters, Crassostrea gigas Thunberg. - J. Fish Dis. 3, 1-10.

Farley, C. A., 1969. Probable neoplastic disease of the hematopoietic system in oysters, Crassostrea virginica and Crassostrea gigas, - Natn Cancer Inst. Monogr. 31, 541-555.

Farley, C. A., 1976. Ultrastructural observations on epizootic neoplasia and lytic virus infection in bivalve mollusks. - Prog. exp. Tumor Res, 20, 283-294.

Farley, C. A., 1978. Viruses and viruslike lesions in marine mollusks. - Mar. Fish. Rev. 40 (10), $18-20$.

Farley, C. A., 1981, Phylogenetic relationships between viruses, marine invertebrates and neoplasia. In: Phyletic approaches to cancer. Ed. by C. J. Dawe. Japan Sci. Soc. Press, Tokyo, 75-87.

Farley, C. A, Banfield, W. C., Kasnic, G., Jr, \& Foster, W. S., 1972. Oyster herpes-type virus. Science, N.Y. 178, 759-760.

Federici, B. A. \& Hazard, E. I., 1975. Iridovirus and cytoplasmic polyhedrosis virus in the freshwater daphnid Simocephalus expinosus. - Nature, Lond. 254, 327-328.

Federici, B. A. \& Humber, R. A., 1977. A possible baculovirus in the insect-parasitic fungus, Strongwellsea magna. - J. gen. Virol. 35, 387-391.

Foster, C. A., Farley, C. A. \& Johnson, P. T., 1981. Virus-like particles in cardiac cells of the brown shrimp, Penaeus aztecus Ives. - J. submicrosc. Cytol. 13, 723-726.

Franc, A. \& Arvy, L., 1969. Sur Thanatostrea polymorpha n. g., n. sp., agent de destruction des branchies et des palpes de l'huître portugaise. - C. r. hebd. Séanc. Acad. Sci., Paris (D) 268, 3189-3190.

Harshbarger, J. C., Otto, S. V. \& Chang, S. C., 1977. Proliferative disorders in Crassostrea virginica and Mya arenaria from the Chesapeake Bay and intranuclear virus-like inclusions in $M y a$ arenaria with germinomas from a Maine oil spill site. - Haliotis $8,243-248$.

Hill, B. J., 1976a. Properties of a virus isolated from the bivalve mollusc Tellina tenuis (Da Costa). Proc. int. Wildl. Dis. Conf. 3, 445-452.

Hill, B. J., 1976b. Molluscan viruses: Their occurrence, culture and relationships. - Proc. int. Colloq. Invertebr. Pathol, 1, 25-29.

Hill, B. J. \& Alderman, D. J., 1977. Observations on the experimental infection of Ostrea edulis with two molluscan viruses. - Haliotís 8, 297-299.

Hill, B. J., Way, K. \& Alderman, D. J., 1982. Further investigations into the pathogenicity of IPN-like viruses for oysters. - Proc. int. Colloq. Invertebr. Pathol. 3, 273-274.

Hoover, K. L., 1977. The effect of a virus infection on the hemocyte population in Carcinus maenas. Sc. D. Thesis, Johns Hopkins Univ, $158 \mathrm{pp}$.

Hoover, K. L. \& Bang, F. B., 1976. Histopathological effects of a virus infection in the shore crab, Carcinus maenas. - Proc, int. Colloq. Invertebr. Pathol. 1, 310-311.

Jahromi, S. S, 1977. Occurrence of rhabdovirus-like particles in the blue crab, Callinectes sapidus. - J. gen. Virol. 36, 485-494.

Johnson, P. T., 1976a. A herpeslike virus from the blue crab, Callinectes sapidus. - J. Invertebr. Pathol. 27, 419-420.

Johnson, P. T., 1976b. A baculovirus from the blue crab, Callinectes sapidus, - Proc. int. Colloq. Invertebr. Pathol, 1, 24.

Johnson, P. T., 1977. A viral disease of the blue crab, Callinectes sapidus: Histopathology and differential diagnosis. - J. Invertebr. Pathol. 29, 201-209.

Johnson, P. T., 1978. Viral diseases of the blue crab, Callinectes sapidus. - Mar. Fish. Rev. 40 (10), 13-15.

Johnson, P. T., 1983. Diseases caused by viruses, rickettsiae, bacteria, and fungi. In: The biology of Crustacea. Ed. by A. J. Provenzano. Acad. Press, New York, 6, 1-78. 
Johnson, P. T. \& Bodammer, J. E., 1975. A disease of the blue crab, Callinectes sapidus, of possible viral etiology. - J. Invertebr. Pathol. 26, 141-143.

Johnson, P. T. \& Farley, C. A., 1980. A new enveloped helical virus from the blue crab, Callinectes sapidus. - J. Invertebr. Pathol. 35, 90-92.

Kazama, F. Y. \& Schornstein, K. L, 1972. Herpes-type virus particles associated with a fungus. Science, N.Y. 177, 696-697.

Kuris, A. M., Poinar, G. O., Jr., Hess, R. \& Morris, T. J., 1979. Virus particles in an internal parasite, Portunion conformis (Crustacea: Isopoda: Entoniscidae), and its marine crab host, Hemigrapsus oregonensis. - J. Invertebr. Pathol. 34, 26-31.

Leibovitz, L. \& Comps, M., 1982. Velar cell lesions of larval Pacific oyster (Crassostrea gigas). - Proc. int. Colloq. Invertebr. Pathol. 3, 275-276.

Leibovitz, L., Elston, R., Lipovsky, V. P. \& Donaldson, J., 1978. A new disease of larval Pacific oysters (Crassostrea gigas). - Proc. a. Meet. Whd Maricult. Soc. 9, 603-611.

Lightner, D. V. \& Redman, R. M., 1981. A baculovirus-caused disease of the penaeid shrimp, Penaeus monodon. - J. Invertebr. Pathol. 38, 299-302.

Lightner, D. V., Redman, R. M. \& Bell, T. A., 1983a. Histopathology and diagnostic methods for IHHN and MBV diseases in cultured penaeid shrimp. - Proc. Symp. warm water crustacean Aquacult. Brigham Young Univ., Laie, Hawaii. (In press).

Lightner, D. V., Redman, R. M. \& Bell, T. A., 1983b. Observations on the geographic distribution, pathogenesis and morphology of the baculovirus from Penaeus monodon Fabricius. - Aquaculture 32, 209-233.

Lightner, D. V., Redman, R. M. \& Bell, T. A., 1983c. Infectious hypodermal and hematopoietic necrosis (IHHN), a newly recognized virus disease of penaeid shrimp. - J. Invertebr. Pathol. 42, $62-70$.

Lightner, D. V., Redman, R. M., Bell, T. A. \& Brock, J. A., 1983d. Detection of IHHN virus in Penaeus stylirostris and $P$. vannamei imported into Hawaii from South and Central America. - J. Wld Maricult. Soc. 14. (In press).

MacDonald, R. D. \& Gower, D. A., 1981. Genomic and phenotypic divergence among three serotypes of aquatic birnaviruses (infectious pancreatic necrosis virus). - Virology 114, 187-195.

Matthews, R. E. F., 1982. Classification and nomenclature of viruses, - Intervirology 17, 1-199.

McAllister, P. E., 1979. Fish viruses and viral infections. In: Comprehensive virology. Ed. by $\mathrm{H}$. Frankel-Conrat \& R. R. Wagner. Plenum Press, New York, 14, 401-470.

Meyers, T. R., 1979. A reo-like virus isolated from juvenile American oysters (Crassostrea virginica). $-J$. gen. Virol. 43, 203-212.

Meyers, T. R. \& Hirai, K., 1980. Morphology of a reo-like virus isolated from juvenile American oysters (Crassostrea virginica). - J. gen. Virol. 46, 249-253.

Mix, M. C., 1982. Cellular proliferative disorders in bay mussels (Mytilus edulis) from Oregon estuaries. - Proc. int. Colloq. Invertebr. Pathol. 3, 266-267.

Mix, M. C., Hawkes, J. W. \& Sparks, A. K., 1979. Observations on the ultrastructure of large cells associated with putative neoplastic disorders of mussels, Mytilus edulis, from Yaquina Bay, Oregon. - J. Invertebr. Pathol. 34, 41-56.

Mokhtar-Maamouri, F., Lambert, A., Maillard, C. \& Vago, C., 1976. Infection virale chez un Platyhelminthe parasite. - C. r. hebd. Séanc. Acad. Sci., Paris (D) 283, 1249-1252.

Morrissey, R. E. \& Edwards, J. S., 1977. Viruslike particles in peripheral nerve of the house cricket. J. Invertebr. Pathol. 29, 247-249.

Ohba, M. \& Aizawa, K., 1979. Multiplication of Chilo iridescent virus in noninsect arthropods. - J. Invertebr. Pathol. 33, 278-283.

Ohba, M. \& Aizawa, K., 1981. Lethal toxicity of arthropod iridoviruses to an amphibian, Rana limnocharis. - Arch. Virol. 68, 153-156.

Ohba, M. \& Aizawa, K., 1982. Mammalian toxicity of an insect Iridovirus. - Acta Virol. 26, 165-168.

Ohba, M., Mike, A. \& Aizawa, K., 1982. Multiplication of a crustacean iridovirus in lepidopterous insects. - J. Invertebr. Pathol. 39, 241-243.

Oprandy, J. J., Chang, P. W., Pronovost, A. D., Cooper, K. R., Brown, R. S. \& Yates, V. J., 1981. Isolation of a viral agent causing hematopoietic neoplasia in the soft-shell clam, Mya arenaria. J. Invertebr. Pathol. 38, 45-51. 
Oschman, J. L., 1969. Endonuclear viruslike bodies in Convoluta roscoffensis (Turbellaria, Acoela). - J. Invertebr. Pathol. 13, 147-148.

Overstreet, R. M., 1978. Marine maladies? Worms, germs, and other symbionts from the northern Gulf of Mexico. Mississippi-Alabama Consortium, Ocean Springs, Mississippi, 1-140.

Pappalardo, R. \& Bonami, J.-R., 1979. Infection des Crustacés marins due à un vírus de type nouveau apparenté aux Baculovirus. - C. r, hebd. Séanc. Acad. Sci., Paris (D) 288, 535-537.

Payen, G. G. \& Bonami, J.-R., 1979. Mise en evidence de particules d'allure virale associées aux noyaux des cellules mesodermiques de la zone germinative testiculaire du crabe Rhithropanopeus harrisii (Gould) (Brachyoure, Xanthide), - Revue Trav. Inst. Pêch. marit. 43, 361-365.

Reinisch, C. L., Charles, A. M. \& Troutner, J., 1983. Unique antigens on neoplastic cells of the soft shell clam Mya arenaria. - Dev. comp. Immunol. 7, 33-39.

Reuter, M., 1975. Viruslike particles in Gyratrix hermaphroditus (Turbellaria: Rhabdocoela). - J. Invertebr. Pathol. 25, 79-95.

Rungger, D., Rastelli, M., Braendle, E. \& Malsberger, R. G., 1971. A viruslike particle associated with lesions in the muscles of Octopus vulgaris. - J. Invertebr. Pathol, 17, 72-80.

Sano, T., Nishimura, T., Oguma, K., Momoyama, K. \& Takeno, N., 1981. Baculovirus infection of cultured Kuruma shrimp, Penaeus japonicus in Japan. - Fish Pathol. 15, 186-191.

Steinhaus, E. (Ed.), 1963. Insect pathology. Acad. Press, New York, 1, 1-661.

Underwood, B. O., Smale, C. J., Brown, F. \& Hill, B. J., 1977. The relationship of a virus from Tellina tenuis to infectious pancreatic necrosis virus. - J. gen. Virol, 36, 93-102.

Vacelet, J. \& Gallisian, M.-F., 1978. Virus-like particles in cells of the sponge Verongia cavernicola, (Demospongiae, Dictyoceratida) and accompanying tissue changes. - J. Invertebr, Pathol. 31, 246-254.

Vago, C., 1963. Predispositions and interrelations in insect diseases. In: Insect pathology. Ed. by E. A. Steinhaus, Acad. Press, New York, 1, 339-379.

Vago, C., 1966. A virus disease in Crustacea. - Nature, Lond. 209, 1290.

Yudin, A. I. \& Clark, W. H., Jr., 1978. Two viruslike particles found in the ecdysial gland of the blue crab, Callinectes sapidus. - J. Invertebr. Pathol. 32, 219-221.

Yudin, A. I. \& Clark, W. H., Jr., 1979. A description of rhabdovirus-like particles in the mandibular gland of the blue crab, Callinectes sapidus. - J. Invertebr. Pathol. 33, 133-147.

Zerbib, C., Andrieux, N. \& Berreur-Bonnenfant, J., 1975. Données préliminaires sur l'ultrastructure de la glande du mue (organe Y) chez le Crabe Carcinus mediterraneus sain et parasité par Sacculina carcini. - C. r, hebd. Séanc. Acad. Sci., Paris (D) 281, 1167-1169. 